\title{
Review \\ In Vitro and In Vivo Antidiabetic Potential of Monoterpenoids: An Update
}

\author{
Lina T. Al Kury ${ }^{1, * \mathbb{D}}$, Aya Abdoh ${ }^{2}$, Kamel Ikbariah ${ }^{2}$, Bassem Sadek ${ }^{3}$ and Mohamed Mahgoub $^{4}$ \\ 1 Department of Health Sciences, College of Natural and Health Sciences, Zayed University, \\ Abu Dhabi P.O. Box 144534, United Arab Emirates \\ 2 School of Medicine, Royal College of Surgeons in Ireland-Bahrain, Muharraq P.O. Box 15503, Bahrain; \\ 18253687@rcsi.com (A.A.); $18206441 @$ rcsi.com (K.I.) \\ 3 Zayed Center for Health Sciences, College of Medicine and Health Sciences, \\ United Arab Emirates University, Abu Dhabi P.O. Box 144534, United Arab Emirates; \\ bassem.sadek@uaeu.ac.ae \\ 4 Pharmacy Department, SEHA, Abu Dhabi Health Services, Abu Dhabi P.O. Box 144534, United Arab Emirates; \\ Momahgoub@seha.ae \\ * Correspondence: Lina.AlKury@zu.ac.ae; Tel.: +971-50-6623975
}

Citation: Al Kury, L.T.; Abdoh, A.; Ikbariah, K.; Sadek, B.; Mahgoub, M. In Vitro and In Vivo Antidiabetic Potential of Monoterpenoids: An Update. Molecules 2022, 27, 182. https://doi.org/10.3390/ molecules27010182

Academic Editors: Raffaele Pezzani and Sara Vitalini

Received: 14 November 2021 Accepted: 25 December 2021 Published: 29 December 2021

Publisher's Note: MDPI stays neutral with regard to jurisdictional claims in published maps and institutional affiliations.

Copyright: (C) 2021 by the authors. Licensee MDPI, Basel, Switzerland. This article is an open access article distributed under the terms and conditions of the Creative Commons Attribution (CC BY) license (https:// creativecommons.org/licenses/by/ $4.0 /)$.

\begin{abstract}
Diabetes mellitus (DM) is a chronic metabolic condition characterized by persistent hyperglycemia due to insufficient insulin levels or insulin resistance. Despite the availability of several oral and injectable hypoglycemic agents, their use is associated with a wide range of side effects. Monoterpenes are compounds extracted from different plants including herbs, vegetables, and fruits and they contribute to their aroma and flavor. Based on their chemical structure, monoterpenes are classified into acyclic, monocyclic, and bicyclic monoterpenes. They have been found to exhibit numerous biological and medicinal effects such as antipruritic, antioxidant, anti-inflammatory, and analgesic activities. Therefore, monoterpenes emerged as promising molecules that can be used therapeutically to treat a vast range of diseases. Additionally, monoterpenes were found to modulate enzymes and proteins that contribute to insulin resistance and other pathological events caused by DM. In this review, we highlight the different mechanisms by which monoterpenes can be used in the pharmacological intervention of DM via the alteration of certain enzymes, proteins, and pathways involved in the pathophysiology of DM. Based on the fact that monoterpenes have multiple mechanisms of action on different targets in in vitro and in vivo studies, they can be considered as lead compounds for developing effective hypoglycemic agents. Incorporating these compounds in clinical trials is needed to investigate their actions in diabetic patients in order to confirm their ability in controlling hyperglycemia.
\end{abstract}

Keywords: diabetes mellitus; anti-diabetic drugs; monoterpenes

\section{Introduction}

Diabetes mellitus (DM) is a chronic metabolic condition characterized by endocrine abnormalities and persistent hyperglycemia [1-3]. DM can be classified into several types based on the etiology, clinical manifestations, and management; however, persistent high levels of glucose and hyperlipidemia are the major common aspects between all the major types of DM [4-7]. Due to its complexity, DM and its complications remain a substantial medical problem. Most of the available conventional drugs, despite their therapeutic benefits, can produce some undesirable side effects and are expensive. Therefore, the search for antidiabetic drugs, specifically plant-based medicine, gains importance due to their potential therapeutic effects. Recently, several phytochemicals have been shown to possess antidiabetic properties, and many efforts have been carried out to elucidate their possible antidiabetic mechanisms. Monoterpenes are a group of secondary plant metabolites that are widespread in nature and have significant hypoglycemic effect, which 
has been well-documented in several experimental studies [8-11]. The aim of this review is to overview the activities and the underlying mechanisms by which monoterpenes exhibit their antidiabetic effects against DM. The novelty of this study stems from the fact that it highlights the most recent findings on the mechanisms of monoterpenes in in vitro and in vivo studies using animal models, which in turn provides a window of opportunity for future research in this field.

\section{Diabetes Mellitus and Its Pathogenesis}

DM is classified into four main subtypes including type 1 diabetes mellitus (T1DM), type 2 diabetes mellitus (T2DM), gestational diabetes mellitus [12], and maturity-onset diabetes of the young (MODY) [13]. T1DM, also known as insulin-dependent DM, occurs due to the destruction of insulin-producing $\beta$-cells in the pancreas via autoimmune mechanisms. Consequently, this leads to the scantiness of insulin levels and hence patients require exogenous insulin supply [14-17]. T2DM, however, is characterized by what is known as insulin resistance (IR) $[18,19]$. On the contrary, gestational diabetes is an acute form of DM affecting pregnant women as a result of perturbations in the levels of different hormones such as estrogen, progesterone, and cortisol [4,20]. MODY, the rarest type of DM, results from mutations in the genes involved in glucose metabolism $[5,21]$.

Under normal conditions, the molecular events involved in insulin signaling are initiated by glucose oxidation and its facilitated diffusion into $\beta$-cell by glucose transporter 2 (GLUT2), the main transporter of glucose in the intestine, pancreas, liver, and kidney. Following the entry of glucose, it is phosphorylated by glucokinase enzyme into glucose-6phospahte (G6P) which is considered the sensor for glucose in the pancreatic $\beta$-cell and plays a central function in insulin secretion. Further metabolism of G6P produces ATP, which inhibits ATP-sensitive $\mathrm{K}^{+}$channels and results in membrane depolarization and calcium influx through L-type voltage-dependent calcium channels. The rise in intracellular calcium stimulates insulin release into the bloodstream [22].

Unlike T1DM, pancreatic production of insulin in T2DM may remain intact. However, the action of insulin on various body organs is the cardinal pathological condition which occurs due to IR, causing impaired glucose uptake by muscle tissue, inhibition of hepatic glucose synthesis, and increased lipolysis (Figure 1) [23,24]. Typically, pancreatic $\beta$-cells counteract for the diminished effect of insulin through increasing the release of insulin to reverse hyperglycemia; however, as IR worsens, this compensatory mechanism becomes less effective. Consequently, the insulin-producing capacity of the pancreas progressively diminishes, leading to the eventual loss of pancreatic $\beta$-cells mass, apoptosis, and complete loss of insulin production [25-28]. It is important to mention that insulin sensitivity and/or activity is physiologically regulated by various factors such as circulating hormone levels, plasma lipids, adipokines, and their respective signaling pathways [29-31]. The interaction between those pathways and the insulin pathway tunes the sensitivity and activity of insulin.

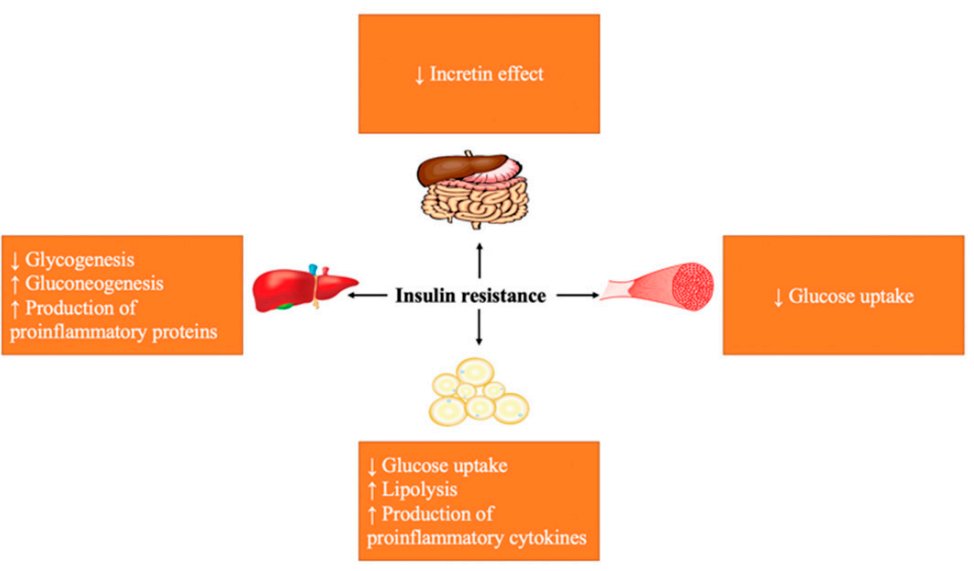

Figure 1. Effects of insulin resistance on body organs and tissues. 
After a meal, approximately two-thirds of the ingested glucose is utilized by skeletal muscles through an insulin-dependent mechanism. Following its binding to its receptor, insulin enhances the migration of the glucose transporter 4 (GLUT4) from the intracellular compartment to the plasma membrane, where it facilitates the uptake of glucose [32,33]. Insulin binds to the $\alpha$-subunit of the insulin receptor (INSR) and causes phosphorylation of tyrosine residues in the $\beta$-subunit, which is followed by the recruitment of different substrates such as insulin receptor substrate-1 (IRS-1), insulin receptor substrate-2 (IRS-2), and phosphoinositide 3-kinase (PI3K) [34]. In addition to the utilization by skeletal muscle, a large portion of glucose is absorbed from the intestines and taken up by hepatocytes to be converted into glycogen via the action of insulin [35]. Upon binding to its receptor, insulin causes a cascade of phosphorylation for several downstream proteins that regulate various metabolic pathways such as gluconeogenesis, glycogen synthesis, glycogenolysis, and lipid synthesis [36]. These metabolic processes are finely tuned by the actions of insulin and glucagon, where insulin promotes glucose storage and glycogen synthesis, while glucagon promotes hepatic glucose production and glycogen breakdown $[35,37,38]$. It is important to mention that development of hepatic IR impairs insulin response in the hepatocytes, which results in the inhibition of glycogen synthesis and the increase in hepatic gluconeogenesis, lipogenesis, and synthesis of proinflammatory proteins such as C-reactive protein (CRP). This can lead to an ongoing inflammatory state in the liver that consequently exacerbates IR $[39,40]$.

Postprandially, insulin binding to its receptor in adipose tissue facilitates the uptake of glucose by GLUT4. This subsequently activates glycolysis, from which glycerol-3phosphate (G3P) is produced and esterified with other fatty acid-forming triacylglycerols that act as a source of energy in the fasting state [41]. Adipose IR impairs the actions of insulin and can therefore lead to impaired uptake of free fatty acids from the blood, enhanced lipolysis, and impaired glucose uptake [42]. At the molecular level, it was found that adipose IR causes activation of a defective form of AKT that impairs the translocation of GLUT4 to the membrane and activates lipolytic enzymes, which consequently worsens hyperglycemia. On the contrary, high levels of free fatty acids in the bloodstream can lead to their accumulation in other organs such as the liver, which eventually affects insulin sensitivity and hepatic gluconeogenesis and worsens T2DM [39,41].

Adipose tissue has a dynamic endocrine role and releases different proteins known as adipokines $[43,44]$. It has been reported that an increase in adipose tissue size and/or mass is associated with fibrosis, hypoxia, macrophage-mediated inflammation, and pathologic vascularization [45]. High-fat diet can stimulate mitochondrial proteins and transcription factors that cause adipose tissue inflammation and dysfunction [46]. The changes in the size of adipocytes and the infiltration of immune cells induce the production of proinflammatory cytokines such as tumor necrosis factor- $\alpha$ (TNF- $\alpha$ ) and interleukins (IL-6 and IL-1 $\beta$ ). This causes a chronic state of inflammation known as metabolic inflammation which plays a significant part in IR and T2DM, consequently [47].

In addition to the above-mentioned events, two types of incretins, namely glucagonlike peptide 1 (GLP-1) and glucose-dependent insulinotropic peptide (GIP) are released from the intestine after meals to stimulate pancreatic insulin secretion $[14,48,49]$. These peptides have a short duration of action due to their deactivation via the dipeptidyl peptidase- 4 (DPP-4) enzyme [50]. While both GLP-1 and GIP share the same effect on insulin secretion [51-53], only GLP-1 can suppress the secretion of glucagon [54,55] and exhibit growth-factor-like effects on pancreatic $\beta$-cells, stimulating insulin gene expression and insulin biosynthesis [56,57]. For this reason, GLP-1 arose as an important pharmacological target in the formulation of antidiabetic therapies via mimicking its effect [58,59]. In T2DM, the action and the level of incretins are adversely affected [60], and the glucose-dependent secretion of insulin is reduced in the fed state $[61,62]$. The pancreas becomes less responsive to GIP, while it remains responsive to GLP-1 [63]. This could be justified by either an uprise in the expression of DPP- 4 or a reduction in the expression of GIP and GLP-1 receptors $[64,65]$. 


\section{Conventional Hypoglycemic Agents}

Up to this day, different pharmacologic agents have been used to limit the effects of hyperglycemia in diabetes. The mechanisms by which hypoglycemia is achieved include stimulation of insulin secretion by sulfonylureas and meglitinides, stimulation of peripheral glucose absorption by thiazolidinediones and biguanides, delay of carbohydrate absorption from the intestine by alpha-glucosidase, and reduction of hepatic gluconeogenesis by biguanides. Combining lifestyle modifications (such as diet and exercise) and using hypoglycemic agents is important to achieve long-term metabolic control and to protect against health complications caused by DM. Several studies investigated this treatment modality and showed the superiority of combining both lifestyle changes and pharmacological agents in the management of T2DM over using antidiabetic agents alone [66-72]. Various injectable and oral therapeutic agents have been developed and used clinically in the management of T2DM, each of which has a unique mechanism of action that targets different pathological events occurring in T2DM $[18,73,74]$ (Figure 2). For example, metformin exhibits its effects by inhibiting hepatic gluconeogenesis [75-77], reducing insulin resistance in skeletal muscle and adipose tissue and promoting the release of GLP-1 [78]. Furthermore, metformin lowers plasma lipid levels by acting on the peroxisome proliferator-activated receptor (PPAR- $\alpha$ ) pathway.

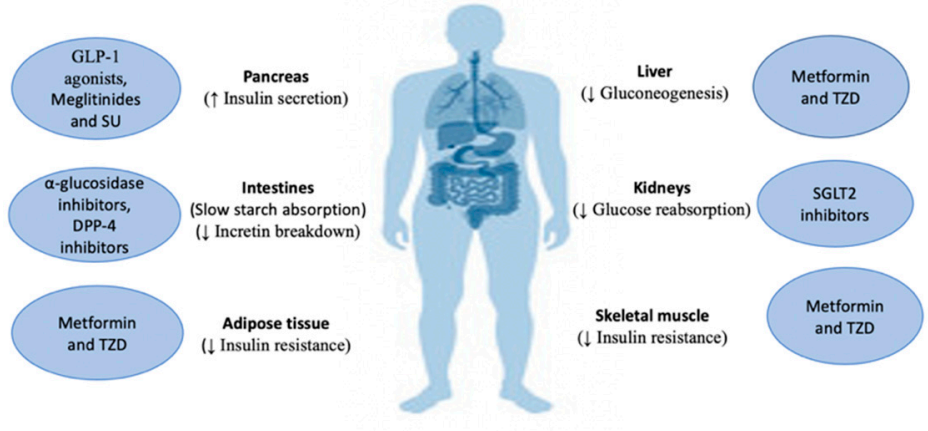

Figure 2. Mechanisms of action of hypoglycemic agents: dipeptidyl peptidase-4 (DPP-4); glucagonlike peptide 1 (GLP-1); sodium-glucose co-transporter-2 (SGLT2); sulfonylureas (SU); thiazolidinediones (TZD).

Sulfonylureas (SU) are insulin secretagogues that exert their action directly on the pancreas by inhibiting ATP-dependent potassium channels on the pancreatic $\beta$-cells, which causes cell depolarization and increases intracellular $\mathrm{Ca}^{2+}$ levels, resulting in insulin secretion [74]. Additionally, they inhibit the breakdown of lipids in the liver and decrease insulin clearance [79]. Although SU are associated with weight gain and hypoglycemic attacks, they remain one of the most widely used agents in the management of T2DM due to their high efficacy in reducing blood glucose levels [80]. Another group of insulin secretagogues are meglitinides, which work through a mechanism similar to that of SU [81]. However, they cause less weight gain and hypoglycemic attacks in comparison to SU, which makes them an ideal alternative for patients complaining of these side effects [74]. Thiazolidinediones (TZD) are a group of drugs that exert their effects by acting on the liver, skeletal muscle, and adipose tissue where they reduce insulin resistance and improve tissue sensitivity to insulin through the activation of PPAR- $\gamma$ [82]. Moreover, TZD can also act on another isoform of PPAR- $\alpha$ which accounts for its lipid-lowering properties. TZD administration results in multiple actions such as maintaining pancreatic $\beta$-cell integrity, decreasing the levels of inflammatory cytokines, and increasing the levels of a protein known as adiponectin that is released from adipose tissue, causing an overall improvement in insulin sensitivity $[27,83]$. Alpha-glucosidase inhibitors such as acarbose, work by inhibiting the enzyme $\alpha$-glucosidase, which functions via the conversion of oligosaccharides into monosaccharides in the small intestines [84]. Acarbose has a similar structure to that of oligosaccharides, which allows it to compete for the binding site in the enzyme. As a 
result, a delay in the postprandial absorption of glucose is achieved along with a reduction in hyperglycemia. The enzyme DPP-4 is responsible for the breakdown of incretin. Due to its physiological function, it arose as a target for the management of T2DM [85]. In 2007, sitagliptin was approved by the Food and Drug Administration (FDA), making it the first DPP-4 inhibitor. By inhibiting DPP-4, the action of incretins is prolonged, which in turn improves insulin secretion, reduces glucagon secretion, and decreases the rate of nutrient absorption into the bloodstream [86,87]. As mentioned previously, GLP-1 agonists became available for use in the management of T2DM in 2005 when the first GLP-1 agonist was approved by the FDA $[88,89]$. GLP-1 and GLP-1 agonists bind to the GLP-1 receptor on pancreatic $\beta$-cells and inhibit ATP-activated $\mathrm{K}^{+}$channels through activation of protein kinase A (PKA)-dependent pathway $[90,91]$. Sodium glucose co-transporter-2 inhibitors are the newest class of oral hypoglycemics that exert their action on renal tubules by suppressing the sodium glucose co-transporter-2, which reduces the reabsorption of glucose and enhances its excretion [28,92-96].

\section{Monoterpenes in Diabetes}

Despite the management of diabetes via the use of conventional pharmacological agents, DM and its complications remain a substantial medical problem. The majority of synthetic oral glucose-lowering drugs exhibit significant side effects and are expensive. Therefore, there has recently been a shift of interest toward exploring natural plant products for their pharmacological effects, including the treatment of diabetes. Monoterpenes are an important group of secondary metabolites that belong to the terpenoids family of natural products and have been recognized for their wide range of cellular and molecular activities that could potentially underlie their positive therapeutic index. Furthermore, their low cost, availability, low undesirable side effects, and better safety profile mark them as promising source for synthesizing new and effective agents to treat DM. For example, monoterpenes such as thymol and carvacrol are common ingredients of food and therefore, not expected to have undesirable effects. Monoterpenes are composed of two isoprene units with a general molecular formula of $\mathrm{C}_{10} \mathrm{H}_{16}$ and frequently contain one double bond in their structures [11]. Monoterpenes exist in over 30 known skeletons and can be classified into three subgroups: acyclic, monocyclic, and bicyclic monoterpenes [97] (Figure 3). Common examples of the acyclic form include linalool, citral, and geraniol, while important representatives of monocyclic monoterpenes include limonene, carveol, and menthol.

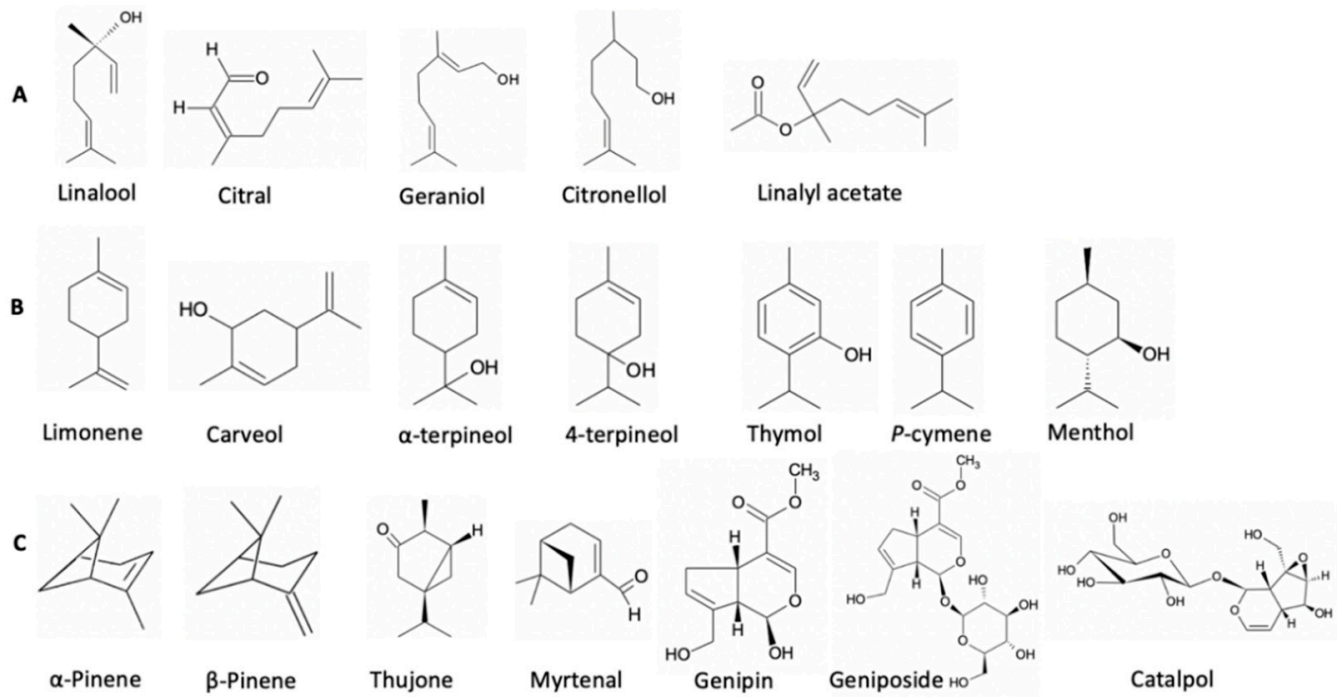

Figure 3. (A) Acyclic monoterpenes, (B) monocyclic monoterpenes, (C) bicyclic monoterpenes. 
According to the size of their second ring, bicyclic monoterpenes can be classified into three classes. The first ring in each class is a six-membered ring while the second can be either a three (e.g., thujone), four (e.g., $\alpha$ - and $\beta$-pinene), or five (e.g., borneol and camphor)-membered ring. Their hydrophobic property along with their small molecular weight makes them the major components found in nearly all essential oils. Studies have reported that both natural monoterpenes and their synthetic derivatives have a vast array of pharmacological actions including anti-diabetic, hypocholesterolemic, antioxidant, antibacterial, anti-inflammatory, anti-cancer, antihistaminic, and analgesic actions [98-100]. This review highlights the potential therapeutic effects of monoterpenes in DM.

\subsection{Acyclic Monoterpenes}

\subsubsection{Linalool}

Linalool (3,7-dimethyl-1,6-octadiene-3-ol) is one of the main monoterpenoids found in herbal essential oils of many plants such as lavender (Lavandula spp.), which is known for its antiarrhythmic effect. Furthermore, linalool is a main component of rose (Rosa spp.), basil (Ocimum basilicum), neroli oil (Citrus aurantium) [101] and found in both green and black tea. Linalool has been implicated in aroma and flavoring [102]. Previous studies have reported potent antioxidant and antidiabetic activity of linalool [103,104]. Linalool was found to have favorable effects on glucose metabolism in animal models of diabetes [105]. Garba et al., 2020 investigated the antidiabetic action of lemongrass tea in T2DM model of rats. The findings of this study have shown that consumption of lemongrass reduced blood glucose levels by $60.3 \%$ [106]. Linalool, one of the main active ingredients of lemongrass, was shown to attenuate hyperglycemia and its associated complications [105]. The results were supported by higher glucose tolerance in lemongrass-treated diabetic rats in comparison to control diabetic rats which could be associated with the high content of linalool [106].

The enzymes $\alpha$-amylase and $\alpha$-glucosidase are accountable for the breakdown of carbohydrates and for the hydrolysis of starch into glucose pre-absorption. A reduction in hyperglycemia postprandially is due to the inhibition of $\alpha$-amylase, which retards carbohydrate digestion and decreases glucose levels in the blood [107]. Therefore, inhibition of carbohydrate digestion in the gastrointestinal tract by $\alpha$-amylase is one of the approaches to treat diabetes. Previous studies have demonstrated that lemongrass could effectively inhibit $\alpha$-amylase and $\alpha$-glucosidase activity [108]. For example, $\alpha$-amylase inhibitory activity of the essential oil of lemon grass, for which linalool is the main active constituent, was found to be fifteen times higher compared to the currently used glucose lowering drug acarbose [109], while the inhibitory activity of methanol extract of lemon grass on $\alpha$-glucosidase was more than $50 \%$ [108].

The uptake of glucose using rat diaphragm is a commonly used method to measure peripheral utilization of glucose in in vitro studies [110]. Linalool demonstrated dosedependent uptake of glucose. At a concentration of $3 \mathrm{mM}$, linalool causes an increased uptake of glucose that is almost equivalent to two units of insulin. Furthermore, linalool was found to reduce oxidative stress and stimulate the activity of the antioxidant enzymes, catalase, and superoxide dismutase [105].

\subsubsection{Citral}

Citral (3,7-dimethylocta-2,6-dienal) is a combination of the cis and trans isomers geranial and neral, and can be found in all citrus fruits and lemon grass (Cymbopogon citratus) [111]. Cymbopogon citratus has been used over the years in Indian traditional medicine as a sedative and to treat headaches and fever [111]. Citral was shown to reduce hyperglycemia and attenuate diabetes-associated complications in earlier studies [112]. A study has reported that citral exhibits a $45.7 \%$ inhibitory effect on $\alpha$-amylase at a concentration of $10 \mathrm{mM}$ [98]. In streptozotocin-treated rats, citral inhibited mammalian $\alpha$-amylase, with an $\mathrm{IC}_{50}$ of $120 \mu \mathrm{M}$, and reduced $\alpha$-amylase levels in vivo. In addition, citral treatment caused a moderate decrease in postprandial glucose and normalized blood lipid profile [112]. Due 
to their direct influence on the control of energy balance via glucose uptake, lipogenesis, and lipolysis, 3T3-L1 adipocytes are among the most commonly used cell culture models to study obesity and T2DM. In 3T3-L1 adipocytes, $1 \mu \mathrm{M}$ of citral was found to suppress the proliferation by $29.2 \%$ [98]. The results of these studies suggest that citral could be a potential antihyperlipidemic agent in diabetes. It is worth noting that several antihyperlipidemic agents such as bile acid sequestrants exhibited a promising glucose lowering activity. Such agents target bile acid receptors, which play a crucial role in metabolic diseases $[113,114]$. In fact, colesevelam, a bile acid sequestrant, caused a significant reduction in $\mathrm{HbA} 1 \mathrm{c}$ and fasting plasma glucose levels. Additionally, it resulted in an increase in the levels of circulating incretins when used by patients with T2DM [115,116]. Furthermore, other types of lipid lowering agents such as fibrates [117] and cholesterol absorption inhibitors such as ezetimibe [118] have also been reported to improve glycemic control and insulin activity through unknown mechanisms.

Citral inhibits the retinaldehyde dehydrogenase enzyme and therefore raises adipose tissue retinaldehyde levels, leading to the inhibition of adipogenesis, increase in metabolic rate, reduction of weight gain, and enhanced tolerance to glucose. Treating 6-week-old male Sprague-Dawley rats with citral (10, 15, and $20 \mathrm{mg} / \mathrm{kg}$ bodyweight for 28 days) caused a noticeable reduction in the increase of body weight. Additionally, citral-treated rats had lower fasting glucose levels, enhanced glucose tolerance and metabolic rate, and lower abdominal fat accumulation [119].

Supporting the above findings, a study recently conducted by Mishra et al., 2019 revealed that citral has antidiabetic as well as dyslipidemic activities. In streptozotocininduced diabetic rats on a high-fat diet, citral application significantly diminished glucose levels in the blood and increased insulin levels in the plasma. Moreover, citral ameliorated oxidative markers along with anti-oxidative enzymes of the pancreas, liver, and adipose tissue, and regulated the activity of the glucose-metabolic enzymes in the liver [120].

\subsubsection{Geraniol}

Geraniol (3,7-dimethylocta-trans-2,6-dien-1-ol) is an acyclic monoterpene alcohol found in many aromatic plants including Cinnamomum tenuipilum and Valeriana officinalis. In traditional medicine, geraniol has been used to treat many ailments including diabetes [121]. In streptozotocin-induced diabetic rats, application of geraniol for 45 days led to a significant dose-dependent increase in insulin levels and reduction in glycated hemoglobin, HbA1c. Furthermore, geraniol was found to ameliorate the function of the enzymes responsible for the metabolism and utilization of glucose. Geraniol additionally improved glycogen content in hepatocytes and preserved the histology of hepatic and pancreatic $\beta$-cells in streptozotocin-induced diabetic rats [122].

A recent work conducted by Kamble et al., 2020 demonstrated for the first time the efficacy of geraniol in inhibiting GLUT2 [123]. Inhibition of GLUT2 in the intestine, liver, and kidney plays a critical role in lowering glucose levels in the blood. Moreover, the inhibition of GLUT2 on pancreatic $\beta$-cells is anticipated to guard $\beta$-cells from glucotoxicity.

Prolonged treatment with geraniol $(29.37 \mathrm{~mm} / \mathrm{kg}$ body weight twice a day for 60 days) enhanced the lipid profile and $\mathrm{HbA1c}$ levels [123]. In another study, $1 \mu \mathrm{M}$ of geraniol resulted in the suppression of 3T3-L1 pre-adipocyte proliferation by $19.9 \%$ [98]. It is clear from these findings that geraniol could be a novel drug in treatment of DM due to the fact that it is effective in lowering blood glucose and improving lipid profile.

\subsubsection{Citronellol}

Citronellol (3,7-dimethyl-6-octen-1-ol) is a linear monoterpene alcohol naturally found in about 70 essential oils, with abundance in Cymbopogon nardus (L.) and citrus oil [124,125]. Cymbopogon nardus was previously used in Chinese medicine to treat rheumatism, fever, and digestive problems [126]. Although citronellol has been reported to possess strong antioxidant, anti-inflammatory, anti-cancer, and cardioprotective properties $[127,128]$, its role in diabetes is not well-investigated. 
Oral administration of citronellol $(25,50$, and $100 \mathrm{mg} / \mathrm{kg}$ bodyweight for 30 days) attenuated the hyperglycemia in streptozotocin-induced diabetic rats. Citronellol improved insulin, hemoglobin, and hepatic glycogen levels and decreased $\mathrm{HbA1c}$ concentration. Furthermore, there was a near to normal restoration of the altered activity of carbohydrate metabolic enzymes as well as hepatic and kidney markers. Citronellol supplement preserved the histology of hepatic cells and pancreatic $\beta$-cells in streptozotocin-treated rats [124].

Glucose uptake plays an important role in the control of plasma glucose level, thus directly influencing glucose tolerance. Treating 3T3-L1 adipocytes with $1 \mu \mathrm{M}$ of citronellol exerted about $16 \%$ enhancement in glucose uptake [98].

\subsubsection{Linalyl Acetate}

Linalyl acetate (3,7-dimethylocta-1,6-dien-3-yl acetate) is the primary constituent of lavender (Lavandula angustifolia) which is known in folk medicine for its sedative effect [129]. It is also a main component of Salvia sclarea oil [130]. It has been shown that linalyl acetate possesses an anti-inflammatory effect and can restore endothelial function in rats after oxidative stress $[104,131]$. To date, the reported therapeutic effects of linalyl acetate in hyperglycemia are scarce. Treatment with $100 \mathrm{mg} / \mathrm{kg}$ linalyl acetate was more efficient in correcting serum glucose than the antidiabetic drug metformin in streptozotocin-induced diabetic rats. In addition, the observed cardiovascular protective and metabolic stabilization effects of linalyl acetate could be attributed to its antioxidative and anti-inflammatory properties, its increase in AMP-activated protein kinase expression, and its suppression of excess serum NO [132]. The antidiabetic effects of acyclic monoterpenes are summarized in Table 1.

Table 1. Antidiabetic effects of acyclic monoterpenes.

\begin{tabular}{|c|c|c|c|c|}
\hline Compound & Model & Concentration & Antidiabetic Activities & References \\
\hline \multirow[t]{2}{*}{ Linalool } & T2DM rat model & $\begin{array}{l}\text { Tea preparation }(0.25 \mathrm{~g} / \\
100 \mathrm{~mL} \text { and } 0.5 \mathrm{~g} / 100 \mathrm{~mL} \text { for } \\
4 \text { weeks })\end{array}$ & $\begin{array}{l}\text { Lowered serum glucose and lipids; } \\
\text { increased insulin sensitivity and } \\
\text { levels of serum insulin; improved } \\
\beta \text {-cell function, increased } \\
\text { liver glycogen }\end{array}$ & [106] \\
\hline & $\begin{array}{l}\text { Diaphragm of } \\
\text { streptozotocin-induced } \\
\text { diabetic rat }\end{array}$ & $3 \mathrm{mM}$ & $\begin{array}{l}\text { Decreased oxidative stress, increased } \\
\text { the activity of the antioxidant } \\
\text { enzymes catalase and } \\
\text { superoxide dismutase. }\end{array}$ & [105] \\
\hline \multirow[t]{6}{*}{ Citral } & Hemi diaphragm of Albino rat & $3 \mathrm{mM}$ & Increased glucose uptake & [105] \\
\hline & $\begin{array}{l}\text { Streptozotocin-induced } \\
\text { diabetic rats }\end{array}$ & $\begin{array}{l}2,8,16 \text { or } 32 \mathrm{mg} / \mathrm{kg} \\
\text { body weight }\end{array}$ & $\begin{array}{l}\text { Inhibited adipogenesis; increased } \\
\text { metabolic rate, reduced weight gain; } \\
\text { enhanced glucose tolerance. }\end{array}$ & [112] \\
\hline & $\begin{array}{l}\text { Streptozotocin-induced } \\
\text { diabetic rats }\end{array}$ & $\begin{array}{l}2,8,16 \text { or } 32 \mathrm{mg} / \mathrm{kg} \\
\text { body weight }\end{array}$ & Inhibition of $\alpha$-amylase. & [112] \\
\hline & 3T3-L1 adipocytes & $1 \mu \mathrm{M}$ & $\begin{array}{l}\text { Suppression of adipocyte } \\
\text { proliferation of by } 29.2 \% \text {. }\end{array}$ & [98] \\
\hline & $\begin{array}{l}\text { 6-week-old male } \\
\text { Sprague-Dawley rats }\end{array}$ & $\begin{array}{l}10,15 \text {, and } 20 \mathrm{mg} / \mathrm{kg} \text { body } \\
\text { weight for } 28 \text { days }\end{array}$ & $\begin{array}{l}\text { Increased energy dissipation; } \\
\text { reduced lipid accumulation; } \\
\text { prevention of diet-induced obesity; } \\
\text { improved insulin sensitivity and } \\
\text { glucose tolerance. }\end{array}$ & [119] \\
\hline & $\begin{array}{l}\text { Streptozotocin-induced diabetic } \\
\text { rats fed with high-fat diet }\end{array}$ & $\begin{array}{l}45 \mathrm{mg} / \mathrm{kg} / \text { body weight for } \\
28 \text { days }\end{array}$ & $\begin{array}{l}\text { Decreased blood glucose and } \\
\text { increased plasma insulin; increased } \\
\text { anti-oxidative enzymes of the liver, } \\
\text { adipose tissue, and pancreas; } \\
\text { regulated enzyme activity of } \\
\text { glycolysis and gluconeogenesis in } \\
\text { the liver. }\end{array}$ & [120] \\
\hline
\end{tabular}


Table 1. Cont.

\begin{tabular}{|c|c|c|c|c|}
\hline Compound & Model & Concentration & Antidiabetic Activities & References \\
\hline \multirow[t]{3}{*}{ Geraniol } & $\begin{array}{l}\text { Streptozotocin-induced } \\
\text { diabetic rats }\end{array}$ & $\begin{array}{l}100,200,400 \mathrm{mg} / \mathrm{kg} \text { body } \\
\text { weight for } 45 \text { days }\end{array}$ & $\begin{array}{l}\text { Increased the levels of insulin and } \\
\text { hemoglobin; decreased plasma } \\
\text { glucose } \mathrm{HbA} 1 \mathrm{c} \text {; ameliorated } \\
\text { carbohydrate metabolism; preserved } \\
\text { normal histological appearance of } \\
\text { hepatic and pancreatic } \beta \text {-cells. }\end{array}$ & {$[122]$} \\
\hline & & $648.34 \mu \mathrm{M}$ & Inhibited GLUT2 transporter. & {$[123]$} \\
\hline & & $\begin{array}{l}60 \text { days with } 29.37 \mathrm{~mm} / \mathrm{kg} \\
\text { B.W. twice a day }\end{array}$ & $\begin{array}{l}\text { Improved lipid profile, } \mathrm{HbA} 1 \mathrm{c} \text { levels } \\
\text { and renal parameters. }\end{array}$ & {$[123]$} \\
\hline \multirow[t]{2}{*}{ Citronellol } & $\begin{array}{l}\text { Streptozotocin-induced } \\
\text { diabetic rats }\end{array}$ & $\begin{array}{l}\text { Oral administration of } 25,50 \text {, } \\
\text { and } 100 \mathrm{mg} / \mathrm{kg} \text { body weight } \\
\text { for } 30 \text { days }\end{array}$ & $\begin{array}{l}\text { Improved levels of insulin, } \\
\text { hemoglobin, and hepatic glycogen; } \\
\text { decreased levels of HbA1c; restored } \\
\text { altered activities of carbohydrate } \\
\text { metabolic enzymes, hepatic and } \\
\text { kidney markers; preserved normal } \\
\text { histological appearance of hepatic } \\
\text { cells and insulin-positive } \beta \text {-cells }\end{array}$ & {$[124]$} \\
\hline & 3T3-L1 adipocytes & $1 \mu \mathrm{M}$ & Enhanced glucose uptake & [98] \\
\hline Linalyl acetate & $\begin{array}{l}\text { Streptozotocin-induced } \\
\text { diabetic rats }\end{array}$ & $100 \mathrm{mg} / \mathrm{kg}$ & $\begin{array}{l}\text { Decreased serum glucose; reduced } \\
\text { oxidative stress and inflammation }\end{array}$ & {$[132]$} \\
\hline
\end{tabular}

\subsection{Monocyclic Monoterpene}

\subsubsection{Limonene}

Limonene [1-methyl-4-(1-methylethenyl)-cyclohexene] is the main constituent of oils extracted from orange, lemon, grapefruit, and other citrus plants. It is also frequently used as a food additive, and a constituent of soaps and perfumes. As per the Code of Federal Regulations, D-limonene is classified as a safe flavoring compound [133].

Limonene was shown to reduce hyperglycemia and attenuate diabetes-associated complications in earlier studies $[105,134]$. Inhibition of protein glycation is known to improve secondary complications in diabetes. In streptozotocin-induced diabetic rats, limonene $(100 \mu \mathrm{M})$ revealed $85.61 \%$ reduction in protein glycation [105]. In a study conducted by Joglekar et al., 2013, limonene was shown to inhibit protein glycation by $56.3 \%$ at a concentration of $50 \mu \mathrm{M}$. Furthermore, BSA was used as a model protein in PatchDock studies, which have shown that limonene has the ability to bind to the key glycation sites IB, IIA, and IIB sub domains. It was concluded that limonene is a powerful inhibitor of protein glycation that exhibits its effects by a novel mechanism of stabilization of protein structure through hydrophobic interactions [135]. In 3T3-L1 adipocytes, $1 \mu \mathrm{M}$ of (R)-(+)-limonene stimulated both the uptake of glucose and breakdown of fats. It also upregulated glucose transporter 1 (GLUT1) expression and suppressed adipose triglyceride lipase (ATGL). (R)-(+)-limonene (at $\mathrm{mM}$ range) also suppressed both $\alpha$-amylase and $\alpha$-glucosidase; however, such outcome was weak [98].

In oral streptozotocin-induced diabetic rats, administration of D-limonene (50, 100 and $200 \mathrm{mg} / \mathrm{kg}$ body weight) for 45 days resulted in a significant drop in plasma glucose and $\mathrm{HbA1c}$ levels. Furthermore, it resulted in a decrease in the activity of the enzymes involved in gluconeogenesis, including glucose 6-phosphatase (G6Pase) as well as fructose 1,6-bisphosphatase. On the contrary, D-limonene inhibited liver glycogen as well as the activity of the glycolytic enzyme glucokinase in diabetic rats. Such antidiabetic effects were proportional with glibenclamide [136]. These findings support the potential antihyperglycemic activity of D-limonene reported in the literature.

Limonene, alone and in combination with linalool, was found to reduce oxidative stress and intensify the activity of the antioxidant enzymes catalase and superoxide dismutase [105]. The shielding role of D-limonene against diabetes and its complications was demonstrated by Bacanlı et al., 2017 [134]. In streptozotocin-induced diabetic rats, D-limonene treatment ( $50 \mathrm{mg} / \mathrm{kg}$ body weight for 28 days) caused a remarkable reduction 
in DNA damage, glutathione reductase enzyme activity, and malondialdehyde (MDA) levels in the plasma. In addition, it caused a significant increase in the levels of glutathione and the activities of catalase, superoxide dismutase, and glutathione peroxidase. Overall, lipid levels and liver enzymes were adjusted in diabetic rats [134].

\subsubsection{Carveol}

The monoterpene carveol [2-methyl-5-(prop-1-en-2-yl)cyclohex-2-en-1-ol] is a component of the essential oils of Cymbopogon giganteus [137], Illicium pachyphyllum [138], and Carum carvi [139]. It is also present in orange peel, caraway seeds, and dill. Carveol is broadly used in perfumes, soap, and shampoos [140] and has several pharmacological activities including antioxidant, anticancer [141], antimicrobial [99], and anti-inflammatory [142] effects. In addition, carveol has a low toxicity profile [143].

Recently, the antidiabetic capacity of carveol was evaluated in in vivo, in vitro, and in silico studies. In alloxan-induced diabetic rats, carveol caused concentration- and timedependent decrease in the level of glucose in the blood. Carveol (394.1 $\mu \mathrm{M} / \mathrm{kg})$ amended oral glucose tolerance surplus in rats and attenuated the $\mathrm{HbA1c}$ level and mediated hepatoprotective and anti-hyperlipidemic effects [8]. In in vitro assay, carveol inhibited $\alpha$-amylase activity in a dose-dependent manner. In addition, carveol revealed binding affinity toward different targets associated with diabetes. In silico evaluation showed that carveol had maximum binding affinity (lowest energy value) toward the sodium-glucose co-transporter, intermediate binding affinity against fructose-1,6-bisphosphatase, and lowest affinity toward phosphoenolpyruvate carboxykinase (PEPCK) and glycogen synthase kinase-3 $\beta$ (PEPCK) [142]. The results of this study support the antidiabetic potential of carveol.

\subsubsection{Terpineol}

Terpineol [2-(4-methyl-3-cyclohexen-1-yl)-2-propanol] is a main constituent of Marjoram (Origanum majorana) and Maritime pine (Pinus pinaster) [144]. Terpineol is widely used in food and household products. Although the antioxidant and anti-inflammatory effects of terpineol have been documented previously, studies highlighting its direct antidiabetic effects are very limited. In a recent study, in vitro $\alpha$-amylase enzymatic assay has shown that both $\alpha$-terpineol and its structural isomer 4-terpineol caused an inhibition in its enzymatic activity by 33\% ( $\left.\mathrm{IC}_{50} 1.01 \pm 0.0221 \mathrm{mg} / \mathrm{mL}\right)$ and $40 \%\left(\mathrm{IC}_{50} 0.838 \pm 0.0335 \mathrm{mg} / \mathrm{mL}\right)$ respectively, when tested individually at a concentration of $0.670 \mathrm{mg} / \mathrm{mL}$ [145]. Furthermore, terpineol was recently reported to upregulate insulin sensitivity and lessen serum levels of pro-inflammatory cytokines in rats fed with high fat diet [146].

\subsubsection{Thymol}

Thymol (2-isopropyl-5-methylphenol), a natural phenolic monoterpenoid obtained mainly from the Thymus species (Trachyspermum ammi L. Sprague) [145], has been used in folk medicine to treat various ailments such as diabetes and respiratory disorders [147]. Thymol is a potent antioxidant and scavenger for hydroxyl radicals and superoxide anions [148]. Earlier studies on thymol have reported antimicrobial [149], anti-inflammatory [150], as well as anticancer potential [151].

In obese murine model fed with high fat diet, thymol treatment decreased body weight gain as well as visceral fat-pad weight. Additionally, an overall reduction in the levels of lipids was observed. The enzymes alanine aminotransferase, aspartate aminotransaminase, and lactate dehydrogenase were also reduced. Furthermore, thymol decreased the levels of glucose and leptin, decreased serum lipid peroxidation, and improved the levels of antioxidants [152]. Similarly, in mice fed with high-fat diet, thymol treatment $(20,40 \mathrm{mg} / \mathrm{kg}$ daily) significantly reversed body weight gain and peripheral insulin resistance [153]. Saravanan and Pari, (2015) tested the antihyperglycemic and antihyperlipidemic effects of thymol in diabetic C57BL/6J mice fed with high-fat diet. Daily intragastric application of thymol (40 mg/kg body weight) for 5 weeks caused a significant decline in plasma glucose, $\mathrm{HbA1c}$, insulin resistance, and leptin. Moreover, it lowered the levels of plasma triglyc- 
erides, total cholesterol, free fatty acids, and low-density lipoprotein. On the other hand, thymol increased high density lipoprotein cholesterol. In addition, thymol significantly decreased hepatic lipid content including triglycerides, free fatty acids, total cholesterol, and phospholipids [154]. More recently, Saravanan and Pari [155] have shown that thymol possesses a protective role against diabetic nephropathy in C57BL/6J mice. Thymol hindered the activation of transforming growth factor- $\beta 1$ (TGF- $\beta 1$ ) and vascular endothelial growth factor (VEGF). In addition, it caused a substantial increase in the antioxidants, inhibited lipid peroxidation markers in erythrocytes and kidney tissue and reduced the lipid accumulation in kidney [156].

Supporting these results, a more recent study has shown that in streptozotocin-treated diabetic rats, 20 and $40 \mathrm{mg} / \mathrm{kg}$ thymol significantly reduced the levels of creatinine, lowdensity lipoprotein cholesterol, and hepatic enzymes including aspartate aminotransferase and alanine aminotransferase. Furthermore, the antioxidant enzyme status was also modulated after treatment with thymol [157]. Such findings indicate that thymol may possess promising protective and anti-diabetic activity.

The antidiabetic and antioxidant properties of Thymus quinquecostatus Celak, of which thymol is the main active constituent, were investigated. High level of thymol in T. quinquecostatus shows the potential of this plant as a crude drug and dietary health supplement. The ethyl acetate fraction of the methanol crude extract of T. quinquecostatus possessed a strong antioxidant activity. In hexane fraction, $\alpha$-glucosidase inhibitory activity was positively correlated with the amount of thymol, indicating that thymol is the primary source for antioxidant and antidiabetic activity of T. quinquecostatus [158].

The inhibitory activity of thymol $(5.0 \mathrm{mg} / \mathrm{mL})$ and its synergistic effect with $p$-cymene $(2.5 \mathrm{mg} / \mathrm{mL})$ were linked to their antioxidant property by reducing the formation of advanced glycation end products. Based on spectroscopic and electrochemical methods, in combination with molecular docking study, it was found that the binding affinity of thymol with bovine serum albumin is greater than glucose. Furthermore, thymol had a protective effect toward arginine or lysine modification, indicating that it has an antiglycation property [9].

\subsection{5. $p$-Cymene}

$p$-Cymene [1-methyl-4-(1-methylethyl) benzene] is an essential oil component found in over 100 plants, including Cuminum cyminum and thyme. Due to its use as an intermediate in the industrial manufacturing of food flavoring, fragrances, herbicides, and medications, p-Cymene possesses a significant commercial role [159,160]. $p$-Cymene is the biological precursor of carvacrol and has a structure that is similar to thymol [161]. Earlier studies have reported antioxidant [162] and anti-inflammatory [160] activity of $p$-cymene. In high fat diet-treated adult NMRI mice, $p$-cymene $(20 \mathrm{mg} / \mathrm{kg})$ led to an apparent drop in blood glucose levels as well as alanine aminotransferase and alkaline phosphatase. Additionally, a slight alteration was detected in lipid profile. Interestingly, the effects of $p$-cymene were comparable with metformin [163]. Similar findings were also observed with thymol [152].

In streptozotocin-induced diabetic rats, administration of $p$-cymene $(20 \mathrm{mg} / \mathrm{kg}$ body weight for 60 days) was found to lower $\mathrm{HbA1c}$. Biophysical studies showed that $p$-cymene can inhibit glycation-mediated conversion of $\alpha$-helix to $\beta$-pleated sheet structure of bovine serum albumin. Interestingly, it produced antiglycation effects when used in concentrations that were 10-20 times less than the known protein glycation inhibitors, without exhibiting any toxic effects [164].

\subsubsection{Menthol}

Menthol [5-methyl-2-(propan-2-yl) cyclohexan-1-ol], is a component of essential oils such as eucalyptus and lemongrass and is responsible for the characteristic smell and flavor of Mentha longifloia that has been used traditionally in Asia for the treatment of respiratory illnesses. Menthol occurs in four isomers namely, (+)- and (-)-menthol, (+)- and $(-)$-neomenthol, (+)- and (-)-neoisomenthol, and (+)- and (-)-isomenthol; however, (-)- 
menthol (L-menthol) is the major form that exists in nature [165]. Menthol is used to treat several conditions including the common cold and other respiratory conditions, gastrointestinal disorders, as well as musculoskeletal pain [166]. In streptozotocin-nicotinamide induced diabetic rats, application of menthol $(25,50$, and $100 \mathrm{mg} / \mathrm{kg} /$ body weight $)$ and glibenclamide $(600 \mu \mathrm{g} / \mathrm{kg} /$ body weight) for 45 days caused a significant reduction in the overall levels of blood glucose and $\mathrm{HbA1c}$. It also resulted in an increase in the level of plasma insulin, liver glycogen, and total hemoglobin. Furthermore, menthol ameliorated glucose-metabolizing enzymes, protected hepatic and pancreatic islets, and suppressed pancreatic $\beta$-cells apoptosis in diabetic rats. The later effect was coupled with a rise in anti-apoptotic Bcl-2 expression and a fall in pro-apoptotic Bax expression [167]. In a more recent study, acute oral $(200 \mathrm{mg} / \mathrm{kg})$ and topical administration $(10 \% \mathrm{w} / \mathrm{v})$ of menthol to high fat-fed diabetic mice were found to increase serum glucagon concentration $2 \mathrm{~h}$ after administration. Furthermore, chronic oral administration of menthol (50 and $100 \mathrm{mg} / \mathrm{kg} / \mathrm{day}$ ) for 12 weeks and topical application $(10 \% w / v)$ prevented high fat diet-induced weight gain, adipose tissue hypertrophy, liver triacylglycerol depletion, and insulin resistance. The consequent metabolic changes of menthol in the liver and adipose tissue imitated the role of glucagon. In the liver, an increase in glycogenolysis and gluconeogenesis was observed. Additionally, the thermogenic activity of adipose tissue was boosted. Interestingly, in mature 3T3L1 adipocytes, treatment with the serum of menthol-treated mice improved the markers of energy expenditure, which was blocked following the administration of the non-competitive glucagon receptor antagonist, L-168,049. This effect shows that the increase in serum glucagon induced by menthol administration is responsible for the rise in energy expenditure [168]. The antidiabetic effects of monocyclic monoterpenes are summarized in Table 2.

Table 2. Antidiabetic effects of monocyclic monoterpenes.

\begin{tabular}{|c|c|c|c|c|}
\hline Compound & Model & Concentration & Antidiabetic Activities & References \\
\hline \multirow[t]{6}{*}{ Limonene } & Streptozotocin-induced diabetic rats & $50 \mu \mathrm{M}$ and $100 \mu \mathrm{M}$ & Inhibited protein glycation. & {$[105,135]$} \\
\hline & Streptozotocin-induced diabetic rat & $100 \mu \mathrm{M}$ & $\begin{array}{l}\text { Increased activity of catalase and } \\
\text { superoxide dismutase. }\end{array}$ & {$[105]$} \\
\hline & 3T3-L1 adipocytes & $1 \mu \mathrm{M}$ & $\begin{array}{l}\text { Increased glucose uptake and lipolysis; } \\
\text { upregulated mRNA expression GLUT1 and } \\
\text { suppressed ATGL. }\end{array}$ & [98] \\
\hline & & $\mathrm{mM}$ range & Inhibited $\alpha$-amylase and $\alpha$-glucosidase & {$[98]$} \\
\hline & & $50 \mathrm{mg} / \mathrm{kg}$ body weight & $\begin{array}{l}\text { Decreased DNA damage, decreased } \\
\text { glutathione reductase enzyme activity, } \\
\text { decreased the levels of MDA in the plasma; } \\
\text { increased total glutathione levels, catalase, } \\
\text { superoxide dismutase and glutathione } \\
\text { peroxidase activities }\end{array}$ & [134] \\
\hline & & $\begin{array}{l}50,100 \text { and } 200 \mathrm{mg} / \mathrm{kg} \\
\text { body weight and for } \\
45 \text { days }\end{array}$ & $\begin{array}{l}\text { Increased plasma glucose, HbA1c levels, } \\
\text { and activities of gluconeogenic enzymes; } \\
\text { decreased the activity of glucokinase. }\end{array}$ & [136] \\
\hline Carveol & Alloxan-induced diabetic rat & $394.1 \mu \mathrm{M} / \mathrm{kg}$ & $\begin{array}{l}\text { Improved oral glucose tolerance overload } \\
\text { in; decreased the level of } \mathrm{HbA} \mathrm{A} \text {; inhibited } \\
\alpha \text {-amylase activity. }\end{array}$ & {$[8]$} \\
\hline Terpineol & $\alpha$-amylase enzymatic assay & $\begin{array}{l}\alpha \text {-terpineol } 0.670 \mathrm{mg} / \mathrm{mL} \\
\text { 4-terpineol } \\
0.670 \mathrm{mg} / \mathrm{mL}\end{array}$ & $\begin{array}{l}\text { Inhibited } \alpha \text {-amylase activity } \\
\text { Inhibited } \alpha \text {-amylase activity }\end{array}$ & [145] \\
\hline Thymol & $\begin{array}{l}\text { High-fat diet induced T2DM in } \\
\text { C57BL/6J mice }\end{array}$ & $\begin{array}{l}\text { Intragastric administration } \\
\text { of } 40 \mathrm{mg} / \mathrm{kg} \text { body weight } \\
\text { daily for } 5 \text { weeks. }\end{array}$ & $\begin{array}{l}\text { Decreased plasma glucose, insulin } \\
\text { resistance, HbA1c, leptin and adiponectin; } \\
\text { lowered the levels of plasma triglyceride, } \\
\text { total cholesterol, free fatty acids, low } \\
\text { density lipoprotein; increased high density } \\
\text { lipoprotein cholesterol; decreased in } \\
\text { hepatic lipid content. }\end{array}$ & {$[154]$} \\
\hline
\end{tabular}


Table 2. Cont.

\begin{tabular}{|c|c|c|c|c|}
\hline Compound & Model & Concentration & Antidiabetic Activities & References \\
\hline & C57BL/6J mice & $\begin{array}{l}40 \mathrm{mg} / \mathrm{kg} \text { body weight } \\
\text { daily for } 5 \text { weeks }\end{array}$ & $\begin{array}{l}\text { Protected against diabetic nephropathy; } \\
\text { inhibited the activation of transforming } \\
\text { growth factor- } \beta 1 \text { (TGF- } \beta 1 \text { ) and vascular } \\
\text { endothelial growth factor (VEGF), elevated } \\
\text { antioxidants, inhibited lipid peroxidation } \\
\text { markers in erythrocytes and kidney tissue, } \\
\text { reduced the lipid accumulation in kidney }\end{array}$ & {$[156]$} \\
\hline & $\begin{array}{l}\text { High-fat diet-induced obesity in } \\
\text { murine model }\end{array}$ & $\begin{array}{l}14 \mathrm{mg} / \mathrm{kg} \text { orally twice a } \\
\text { day to } 4 \text { weeks }\end{array}$ & $\begin{array}{l}\text { Decreased body weight gain, visceral } \\
\text { fat-pad weights, lipids, alanine } \\
\text { aminotransferase, aspartate } \\
\text { aminotransaminase, lactate dehydrogenase, } \\
\text { glucose, insulin, and leptin levels }\end{array}$ & {$[152]$} \\
\hline & Streptozotocin-induced diabetic rats & 20 and $40 \mathrm{mg} / \mathrm{kg}$ thymol & $\begin{array}{l}\text { Reduced creatinine, low-density } \\
\text { lipoprotein cholesterol, and liver } \\
\text { function-related enzymes, aspartate } \\
\text { aminotransferase and } \\
\text { alanine aminotransferase }\end{array}$ & {$[157]$} \\
\hline & $\begin{array}{l}\text { 1,1-dephenyl-2-picryl-hydrazyl free } \\
\text { radical scavenging and a reducing } \\
\text { power assay }\end{array}$ & & Increased radical scavenging activity & {$[158]$} \\
\hline & In vitro $\alpha$-glucosidase assay & & Decreased $\alpha$-glucosidase activity & {$[158]$} \\
\hline \multirow[t]{2}{*}{ p-Cymene } & High-fat diet fed adult NMRI mice & $\begin{array}{l}20 \mathrm{mg} / \mathrm{kg} \text { body weight for } \\
6 \text { weeks }\end{array}$ & $\begin{array}{l}\text { Decreased levels of blood glucose, alanine } \\
\text { aminotransferase and alkaline } \\
\text { phosphatase; altered lipid profile. }\end{array}$ & {$[163]$} \\
\hline & Streptozotocin-induced diabetic rat & $\begin{array}{l}20 \mathrm{mg} / \mathrm{kg} \text { body weight for } \\
60 \text { days }\end{array}$ & $\begin{array}{l}\text { Lowered } \mathrm{HbA} 1 \mathrm{c} \text {, prevented } \\
\text { glycation-mediated transition of } \alpha \text {-helix to } \\
\beta \text {-pleated sheet structure of bovine } \\
\text { serum albumin. }\end{array}$ & {$[164]$} \\
\hline \multirow[t]{4}{*}{ Menthol } & High-fat diet fed mice & $\begin{array}{l}\text { Acute oral }(200 \mathrm{mg} / \mathrm{kg}) \\
\text { and topical administration } \\
(10 \% w / v)\end{array}$ & Increased serum glucagon concentration; & {$[168]$} \\
\hline & & $\begin{array}{l}\text { Chronic oral } \\
\text { administration (50 and } \\
100 \mathrm{mg} / \mathrm{kg} / \text { day for } \\
12 \text { weeks) and topical } \\
\text { Application }(10 \% \mathrm{w} / \mathrm{v})\end{array}$ & $\begin{array}{l}\text { Prevented high fat diet-induced weight } \\
\text { gain, insulin resistance, adipose tissue } \\
\text { hypertrophy and triacylglycerol deposition } \\
\text { in liver. }\end{array}$ & {$[168]$} \\
\hline & $\begin{array}{l}\text { Mature 3T3L1 adipocytes treated with } \\
\text { serum of menthol-treated mice in }\end{array}$ & $0.3 \mu \mathrm{M}$ & $\begin{array}{l}\text { Improved energy expenditure markers, } \\
\text { which was blocked in the presence of } \\
\text { non-competitive glucagon receptor } \\
\text { antagonist, L-168,049. }\end{array}$ & {$[168]$} \\
\hline & $\begin{array}{l}\text { Streptozotocin-nicotinamide -induced } \\
\text { diabetic rats }\end{array}$ & $\begin{array}{l}25,50, \text { and } \\
100 \mathrm{mg} / \mathrm{kg} / \text { body weight } \\
\text { for } 45 \text { days }\end{array}$ & $\begin{array}{l}\text { Reduced the level of blood glucose and } \\
\text { HbA1c; increased the level of total } \\
\text { hemoglobin, plasma insulin, and liver } \\
\text { glycogen. }\end{array}$ & {$[167]$} \\
\hline
\end{tabular}

\subsection{Bicyclic Monoterpenes}

\subsection{1. $\alpha$ - and $\beta$-Pinene}

$\alpha$-pinene [(1S,5S)-2,6,6-trimethylbicyclo[3.1.1]hept-2-ene $((-)-\alpha$-Pinene $)]$, is a major component of the volatile oil extract of the herb Foeniculum vulgare (fennel). Earlier studies have reported anti-inflammatory, hypoglycemic, and hepatoprotective effects of fennel [169]. In alloxan-induced diabetic mice, $\alpha$-pinene evoked hypoglycemia at the $2 \mathrm{nd}$ and 24 th hours of treatment. In addition, it was reported that $\alpha$-pinene possesses a strong anti-inflammatory effect at a concentration of $0.50 \mathrm{~mL} / \mathrm{kg}$ [169].

$\beta$-Pinene [6,6-dimethyl-2-methylidenebicyclo[3.1.1]heptane Pin-2(10)-ene] is found in numerous essential oils which possess antioxidant potential. It is one of the key constituents of the hexanic extract of Eryngium carlinae, commonly referred to as the "frog herb", which has been shown to reduce hyperglycemia and hyperlipidemia and exert antioxidant activity in diabetic rats $[170,171]$. 
Pistacia atlantica has been proposed to have a protective effect against conditions associated with oxidative stress [172]. A- and $\beta$-Pinene are the main constituents of gum essential oil of P. atlantica. Administration of the essential oil to diabetic rats caused a significant decrease in MDA and increase in glutathione, glutathione peroxidase, superoxide dismutase, and catalase [173]. In a recent study, in vitro $\alpha$-amylase enzymatic assay has shown that both $\alpha$-pinene $\left(\mathrm{IC}_{50} 1.05 \pm 0.0252 \mathrm{mg} \mathrm{mL}^{-1}\right)$ and $\beta$-pinene $\left(\mathrm{IC}_{50} 1.17 \pm 0.0233 \mathrm{mg} \mathrm{mL}^{-1}\right)$ resulted in a $32 \%$ and $29 \%$ drop in enzymatic activity respectively [145].

\subsubsection{Thujone}

Thujone [(1S,4R,5R)-4-methyl-1-propan-2-yl)bicyclo[3.1.0]hexan-3-one] occurs mainly as a mixture of $\alpha$ and $\beta$ diastereoisomers in many plants including Salvia officinalis $\mathrm{L}$. (sage), Artemisia absinthium L., and Thuja occidantalis L. Traditionally, it was used by native Americans as a remedy for several ailments such as headache, constipation, wounds, and birthmarks. This monoterpene is commonly used as a flavoring substance in food and beverages [174]. Interestingly, sage tea is known for its metformin-like effect, in particular for the essential oil fraction which contains thujone. Therefore, thujone could possibly exhibit some sort of an antidiabetic effect [175]. Nevertheless, animal studies that have pointed to the potential antidiabetic activity of thujone are limited. For example, in soleus muscles, palmitate-induced insulin resistance was assessed in the presence of thujone $(0.01 \mathrm{mg} / \mathrm{mL})$. Initially, insulin resistance was induced with high concentrations of palmitate [176]. Subsequently, the ability of thujone to restore sensitivity to insulin while preserving high palmitate concentrations was tested. The findings of this study indicated that thujone can ameliorate palmitate oxidation and prevent palmitate-induced insulin resistance via AMPactivated protein kinase (AMPK)-dependent pathway that involves partial restoration of insulin-stimulated translocation of GLUT4 [177]. Al-Haj Baddar, et al., 2011 demonstrated that oral administration of $5 \mathrm{mg} / \mathrm{kg}$ body weight of thujone in diabetic rats over 28 days can restore the normal levels of cholesterol and triglycerides [175]. While this finding is promising, the adverse effects of thujone necessitates careful analysis of the results. The narrow therapeutic window of thujone is evident in 2-year studies in rats and mice due to the dose-dependent incidence of seizures [178].

\subsubsection{Myrtenal}

Myrtenal [6,6-dimethylbicyclo[3.1.1]hept-2-ene-2-carbaldehyde] is a natural monoterpene present in plants such as pepper, mint, cumin, and eucalyptus and used as a food additive. It has various biological effects and acts as an antioxidant, anticancer agent, cyclooxygenase-inhibitor, and immunostimulant $[179,180]$. Recently, it was found that myrtenal exhibits antihyperglycemic, antihyperlipidemic, hepatoprotective, and $\beta$-cell protective effects [181,182].

Oral treatment with myrtenal $(20,40$, and $80 \mathrm{mg} / \mathrm{kg}$ body weight) resulted in a significant depletion in plasma glucose and $\mathrm{HbA} 1 \mathrm{c}$ in diabetic rats treated with streptozotocin. Additionally, there was a rise in insulin, hemoglobin $(\mathrm{Hb})$, and glycogen levels in the liver and muscles. An enhancement of the main enzymes involved in carbohydrate metabolism (hexokinase, glucose-6-phosphatase, fructose-1,6-bisphosphatase, and glucose-6-phosphate dehydrogenase) was observed. Furthermore, myrtenal enhanced hepatic enzyme function and restored islet cells and liver histology [182].

In parallel to the above findings, another study has shown that myrtenal-treated diabetic rats displayed a reduction in plasma glucose and a simultaneous rise in plasma insulin. Additionally, myrtenal caused an upregulation in the expression of proteins involved in insulin signaling such as IRS2 (insulin receptor substrate 2), Akt, and GLUT2 in hepatocytes as well as IRS2, Akt, and GLUT4 in skeletal muscle [183].

Recently, the influence of myrtenal on oxidative stress, inflammation, and lipid peroxidation was tested on diabetic rats treated with streptozotocin. Oral administration of $80 \mathrm{mg} / \mathrm{kg}$ body weight of myrtenal for four weeks significantly decreased the diabetesassociated alterations in hepatic and pancreatic cells. This includes antioxidant levels, lipid 
peroxidation, and proinflammatory cytokines such as TNF- $\alpha$, IL-6, and the p65 subunit of nuclear factor-kappa B (NF-kB p65). The findings of this work indicated that myrtenal can potentially act as an antioxidant and anti-inflammatory compound against oxidative stress and inflammation associated with diabetes [184].

\subsubsection{Genipin and Geniposide}

The iridoids genipin [methyl-1-hydroxy-7-(hydrozymethyl)-1,4a,5,7 tetrahydrocyclope nta[c]pyran-4-carboxylate] and geniposide [methyl (1S,4aS,7aS)-7-(hydroxymethyl)-1-[(2S, 3R,4S,5S,6R)-3,4,5-trihydroxy-6-(hydroxymethyl)oxan-2-yl]oxy-1,4a,5,7a tetrahydrocyclope nta[c]pyran-4-carboxylate] exist in many plants as secondary metabolites. The basic structural skeleton of iridoids is a cyclopentane-[C]-pyran ring fused with a six-membered heterocycle oxygenate [185]. At C1 position of the pyran ring, the hydroxyl group can be replaced with a sugar moiety to form the genipin glycoside, geniposide. Genipin is found in unripe Genipa americana L. (genipa) fruits, while geniposide is found in the fruits of Gardenia jasminoides J. (gardenia, Rubiaceae family) that has been used in traditional Chinese medicine for its choleretic and hepatoprotective activity. Earlier studies have shown that geniposide is converted to genipin by the intestinal microflora enzymes, which indicates that genipin is the main form of geniposide in circulating blood [186].

Genipin was shown to have anticancer, anti-inflammatory, hepatoprotective as well as antioxidative activity [187]. Geniposide exhibits many biological effects including antioxidative stress [188], anti-inflammatory [189] and antiapoptosis [190]. In addition, studies have shown that it exerts a promising anti-diabetic activity. For example, in $\mathrm{C}(2) \mathrm{C}(12)$ myotubes, genipin $(10 \mu \mathrm{M})$ stimulated glucose uptake in a time- and concentration-dependent manner. It also enhanced GLUT4 translocation to the cell surface and increased the phosphorylation of IRS-1, AKT, and GSK3 $\beta$. Genipin also caused a rise in ATP levels, which inhibited ATP-dependent $\mathrm{K}^{+}$channels and resulted in elevated cytoplasmic $\mathrm{Ca}^{2+}$ content [191].

Administration of $25 \mathrm{mg} / \mathrm{kg}$ of genipin per day for 12 days to aged rats ameliorated systemic as well as hepatic insulin resistance. It also alleviated hyperinsulinemia, hyperglyceridemia, and hepatic steatosis. Furthermore, genepin reduced hepatic oxidative stress as well as mitochondrial dysfunction. It also improved insulin sensitivity, suppressed cellular ROS overproduction, and alleviated the reduction in mitochondrial membrane potential (MMP) and ATP levels [192]. Guan et al., 2018 studied the effect of genipin on obesity and lipid metabolism in diet-induced obese rats. The findings of this study demonstrated that genipin caused an overall drop in body weight and total fat. Additionally, it reversed insulin and glucose intolerance, dyslipidemia, adipocyte hypertrophy, and hepatic steatosis. It also caused a reduction in serum TNF- $\alpha$ levels [193]. Similar results were reported by Zhong et al., 2018, where genipin alleviated hyperlipidemia and hepatic steatosis in high-fat diet fed mice [194].

Earlier study has shown that geniposide exhibits anti-obesity, anti-oxidant, and insulin resistance-alleviating effects. Additionally, it was shown to adjust abnormal lipid metabolism. In spontaneously obese T2DM TSOD mice, geniposide caused a reduction in visceral fat and body weight and improved lipid metabolism. Furthermore, geniposide had a positive therapeutic impact on glucose tolerance and hyperinsulinemia. Interestingly, geniposide had a direct effect on the liver. In mice treated with free fatty acids, genipin not only inhibited lipid accumulation hepatocytes, but also improved the expression of $\operatorname{PPAR} \alpha$ [195].

Emerging body of evidence revealed that lipotoxicity may be a leading cause of pancreatic $\beta$-cell apoptosis and oxidative stress in diabetes. Increased levels of plasma-free fatty acids not only induce cytotoxicity in pancreatic $\beta$-cells leading to apoptosis, but also promote mitochondrial perturbation, resulting in oxidative stress. In pancreatic INS-1 cells, application of geniposide $(1$ or $10 \mu \mathrm{M})$ for $7 \mathrm{~h}$ alleviated $\beta$-cell apoptosis induced by palmitate and activated caspase- 3 expression. Furthermore, geniposide improved glucose-induced insulin secretion via the activation of GLP-1 receptor [196]. Another study has demonstrated that when INS-1 cells are chronically exposed to elevated glucose 
concentrations, insulin secretion was impaired and cell apoptosis was observed. This change was reversed by the application of geniposide [197]. However, the effects of geniposide on insulin secretion after acute exposure to glucose was dependent on glucose concentration. When INS-1 cells were acutely stimulated with high glucose concentrations, the protective effect of geniposide was diminished. This could be attributed to the capability of geniposide to protect the cells from damage resulting from prolonged release of insulin and glucotoxicity under high glucose load [198].

An earlier study has assessed the direct effect of geniposide on $\beta$-cell function using both rat pancreatic islets and dispersed single islet cells [199]. Geniposide was found to mediate insulin release via the activation of GLP-1R and adenylyl cyclase (AC)/cAMP signaling pathway. In general, the effect of GLP-1R agonists is linked to cAMP signaling [200]. In this study, PKA suppression inhibited geniposide-mediated secretion of insulin, implying that geniposide exhibited its actions mainly via the activation of cAMP-dependent PKA [199]. It is well known that activation of pancreatic voltage-gated $\mathrm{K}^{+}$channels repolarizes cells and suppresses insulin release. Therefore, inhibition of these channels could prolong the duration of the action potential and promote glucose-dependent insulin secretion [201]. Interestingly, Zhang et al., 2016 stated that geniposide can inhibit voltagegated $\mathrm{K}^{+}$channels in a concentration-dependent manner. This was diminished upon treating $\beta$-cells with GLP-1R and PKA inhibitors. Collectively, the findings of this study suggest that inhibition of voltage-gated $\mathrm{K}^{+}$channels is coupled to geniposide-induced insulin release by activating the downstream of GLP-1/cAMP/PKA signaling pathway [199].

\subsubsection{Catalpol}

Catalpol[(2S,3R,4S,5S,6R)-2-[[(1S,2S,4S,5S,6R,10S)-5-hydroxy-2-2(hydroxymethyl)-3,9dioxatricyclo[4.4.0.0 2,4 dec-7-en-10-yl]oxy]-6-(hydroxymethyl) oxane-3,4,5-triol, is an iridoid glucoside isolated from the root of Rehmannia glutinosa, which has previously been used in traditional Chinese medicine to manage hyperglycemia for decades. Earlier studies have reported that catalpol exhibits an antidiabetic potential, which is attributed to its antioxidant property. In animal models, the oral dose of catalpol that caused a significant antidiabetic effect ranged from 2.5 to $200 \mathrm{mg} / \mathrm{kg}$ and 10 to $200 \mathrm{mg} / \mathrm{kg}$ in rats and in mice, respectively [202].

Catalpol acts through several mechanisms that affect insulin-sensitive organs like the liver, skeletal muscle, adipose tissue, and pancreas. Furthermore, catalpol adjusts several genes and proteins in the pancreas, skeletal muscle, and adipose tissue that have a crucial role in the management of diabetes [202].

In high-fat and streptozotocin-treated diabetic C57BL/6J mice, administration of 100 and $200 \mathrm{mg} / \mathrm{kg}$ catalpol over four weeks decreased the $\mathrm{p}$ (Ser 307)-IRS-1 and increased the $\mathrm{p}$ (Ser 347)-AKT and $\mathrm{p}$ (Ser 9)-GSK3 $\beta$. Such effect adjusted the impaired insulin pathway in the liver through PI3K/AKT pathway. Furthermore, catalpol prevented gluconeogenesis by enhancing the activity of AMPK and inhibiting PEPCK and G6Pase protein expression [203]. In spontaneous diabetic $\mathrm{db} / \mathrm{db}$ mice treated with 80 or $160 \mathrm{mg} / \mathrm{kg}$ catalpol for four weeks, p-AMPK and GLUT expression were significantly enhanced in liver, skeletal muscle, as well as adipose tissue, which promoted the uptake of glucose into the cells [204].

In spontaneous diabetic $\mathrm{db} / \mathrm{db}$ mice, the lowered expression of IRS-1 resulted in negative regulation of insulin signaling cascades, as IRS-1 is an important ligand in activating the PI3K/AKT pathway. Furthermore, decreased activity of isocitrate dehydrogenase 2 (IDH2), an enzyme that catalyzes the citrate cycle, attenuates glucose metabolism and ATP production. It is well-known that glucose-6-phosphate 1-dehydrogenase (G6PD2) catalyzes the pentose phosphate pathway that utilizes glucose to produce NADPH and ribose-5phosphate. The downregulation of G6PD2 enzyme decreases the glucose metabolism. On the other hand, upregulation of suppressor of cytokine signaling 3 (SOCS3) enzyme can inhibit the tyrosine phosphorylation of the insulin receptor, leading to the suppression of insulin signaling pathway [205-207]. Liu et al., 2018 reported that oral treatment with catalpol (25, 50, 100, and $200 \mathrm{mg} / \mathrm{kg})$ upregulated IRS-1, IDH2, and G6PD2 expression, 
and downregulated SOCS3. Collectively, the findings indicate that catalpol can increase glucose metabolism through accelerating the citrate cycle and pentose phosphate pathway and promoting insulin signaling pathway [204].

The antidiabetic effects of bicyclic monoterpenes are summarized in Table 3. The mechanisms of action of the above-mentioned monoterpenes are summarized in Figure 4.

Table 3. Antidiabetic effects of bicyclic monoterpenes.

\begin{tabular}{|c|c|c|c|c|}
\hline Compound & Model & Concentration & Antidiabetic Activities & References \\
\hline \multirow[t]{2}{*}{$\alpha$-Pinene } & Alloxan-induced diabetic mice & i.p. injection of $0.25 \mathrm{~mL} / \mathrm{kg} \alpha$-pinene & $\begin{array}{l}\text { Evoked hypoglycemia activity at the 2nd and } \\
\text { 24th hours. }\end{array}$ & [10] \\
\hline & $\alpha$-amylase enzymatic assay & $0.670 \mathrm{mg} / \mathrm{mL}$ & Inhibited $\alpha$-amylase activity. & [145] \\
\hline \multirow[t]{2}{*}{$\beta$-Pinene } & Streptozotocin-induced diabetic rat & $\begin{array}{l}\text { Oral administration of } 30 \mathrm{mg} / \mathrm{kg} \text { of } \\
\text { hexanic extract }(17.53 \% \beta \text {-pinene) } \\
\text { daily for } 7 \text { weeks }\end{array}$ & $\begin{array}{l}\text { Ameliorated hyperglycemia and } \\
\text { oxidative damage. }\end{array}$ & [170] \\
\hline & $\alpha$-amylase enzymatic assay & $0.670 \mathrm{mg} / \mathrm{mL}$ & Inhibited $\alpha$-amylase activity. & [145] \\
\hline \multirow[t]{2}{*}{ Thujone } & $\begin{array}{l}\text { Palmitate-induced insulin resistance } \\
\text { in soleus muscles of male } \\
\text { Sprague-Dawley rats }\end{array}$ & $\begin{array}{l}0.01 \mathrm{mg} / \mathrm{mL} \text { (incubation for } 6 \mathrm{~h} \text { in } \\
\text { presence of palmitate) }\end{array}$ & $\begin{array}{l}\text { Restored insulin sensitivity; ameliorated } \\
\text { palmitate oxidation and rescued } \\
\text { palmitate-induced insulin resistance via } \\
\text { AMPK-dependent mechanism involving partial } \\
\text { restoration of insulin-stimulated } \\
\text { GLUT4 translocation. }\end{array}$ & [177] \\
\hline & $\begin{array}{l}\text { Alloxan monohydrate-induced } \\
\text { diabetic rats }\end{array}$ & $5 \mathrm{mg} / \mathrm{kg}$ thujone for 28 days & $\begin{array}{l}\text { Adjusted cholesterol and triglyceride levels to } \\
\text { normal levels. }\end{array}$ & [175] \\
\hline \multirow[t]{3}{*}{ Myrtenal } & Streptozotocin-induced diabetic rat & 80 mg/kg body weight (orally) & $\begin{array}{l}\text { Adjusted antioxidant levels, lipid peroxidation, } \\
\text { and proinflammatory cytokines (TNF- } \alpha \text {, IL-6, } \\
\text { NF-kB p65). }\end{array}$ & [184] \\
\hline & Streptozotocin-induced diabetic rat & 80 mg/kg body weight (orally) & $\begin{array}{l}\text { Reduced plasma glucose; increased plasma } \\
\text { insulin; upregulated IRS2, Akt, and GLUT2 in } \\
\text { hepatocytes; upregulated IRS2, Akt, and GLUT4 } \\
\text { in skeletal muscle. }\end{array}$ & [183] \\
\hline & Streptozotocin-induced diabetic rat & $\begin{array}{l}20,40 \text {, and } 80 \mathrm{mg} / \mathrm{kg} \text { body } \\
\text { weight (orally) }\end{array}$ & $\begin{array}{l}\text { Depleted plasma glucose and } \mathrm{HbA} 1 \mathrm{c} \text {; increased } \\
\text { insulin, } \mathrm{Hb} \text {, and hepatic and muscle glycogen; } \\
\text { enhanced carbohydrate metabolic enzymes and } \\
\text { hepatic enzyme function; restored islet cells and } \\
\text { liver histology. }\end{array}$ & [182] \\
\hline \multirow[t]{4}{*}{ Genipin } & $\mathrm{C} 2 \mathrm{C} 12$ myotubes & $10 \mu \mathrm{M}$ & $\begin{array}{l}\text { Promoted GLUT4 translocation to the cell } \\
\text { surface; increased the phosphorylation of IRS-1, } \\
\text { AKT, and GSK3 } \beta \text {; increased ATP levels which } \\
\text { inhibited ATP-dependent potassium channels; } \\
\text { increased cytoplasmic calcium. }\end{array}$ & [191] \\
\hline & Aging rats & $\begin{array}{l}25 \mathrm{mg} / \mathrm{kg} \text { genipin or vehicle once daily } \\
\text { for } 12 \text { days }\end{array}$ & $\begin{array}{l}\text { Adjusted insulin resistance; ameliorated } \\
\text { systemic and hepatic insulin resistance; } \\
\text { alleviated hyperinsulinemia, hyperglyceridemia, } \\
\text { and hepatic steatosis; reduced hepatic oxidative } \\
\text { stress and mitochondrial dysfunction; improved } \\
\text { insulin sensitivity; inhibited cellular ROS } \\
\text { overproduction; alleviated the reduction of } \\
\text { levels of MMP and ATP. }\end{array}$ & [192] \\
\hline & Diet-induced obese rats & & $\begin{array}{l}\text { Reduced body fat; Reversed dyslipidemia, } \\
\text { glucose and insulin intolerance, adipocyte } \\
\text { hypertrophy, and hepatic steatosis. Reduced } \\
\text { serum tumor necrosis factor- } \alpha \text { levels. }\end{array}$ & [193] \\
\hline & Diet-induced obese mice & 5 or $20 \mathrm{mg} / \mathrm{kg} /$ day & $\begin{array}{l}\text { Alleviated high-fat diet induced hyperlipidemia } \\
\text { and hepatic steatosis. }\end{array}$ & [194] \\
\hline Geniposide & $\begin{array}{l}\text { Spontaneously obese T2DM } \\
\text { TSOD mice }\end{array}$ & & $\begin{array}{l}\text { Caused a reduction in body weight and visceral } \\
\text { fat accumulation, improved lipid metabolism } \\
\text { and intrahepatic lipid accumulation, adjusted } \\
\text { hyperinsulinemia glucose tolerance, inhibited } \\
\text { the accumulation of lipid in hepatocytes of free } \\
\text { fatty acid treated rats, improved the expression } \\
\text { of PPAR } \alpha \text {. }\end{array}$ & [195] \\
\hline
\end{tabular}


Table 3. Cont.

\begin{tabular}{|c|c|c|c|c|}
\hline Compound & Model & Concentration & Antidiabetic Activities & References \\
\hline & Pancreatic INS- 1 cells & 1 or $10 \mu \mathrm{M}$ for $7 \mathrm{~h}$ & $\begin{array}{l}\text { Alleviated } \beta \text {-cell apoptosis induced by } \\
\text { palmitate, activated caspase- } 3 \text { expression, } \\
\text { improved glucose stimulated insulin secretion } \\
\text { by activating GLP-1R }\end{array}$ & [198] \\
\hline & Pancreatic INS- 1 cells & 1 or $10 \mu \mathrm{M}$ for 5 days & $\begin{array}{l}\text { Increased insulin secretion in } \beta \text {-cells and } \\
\text { decreased apoptosis }\end{array}$ & [197] \\
\hline & $\begin{array}{l}\text { Pancreatic islets and dispersed single } \\
\text { islet cells from Male Sprague- } \\
\text { Dawley (SD) rat }\end{array}$ & 1 and $10 \mu \mathrm{M}$ & $\begin{array}{l}\text { Inhibition of voltage-dependent potassium, } \\
\text { activated GLP-1/cAMP/PKA signaling } \\
\text { pathway and insulin secretion. }\end{array}$ & [199] \\
\hline \multirow[t]{8}{*}{ Catalpol } & $\begin{array}{l}\text { High-fat diet and } \\
\text { streptozotocin-induced diabetic } \\
\text { C57BL/6J mice }\end{array}$ & 100 or $200 \mathrm{mg} / \mathrm{kg}$, p.o., four weeks & $\begin{array}{l}\text { Adjusted the impaired insulin pathway in the } \\
\text { liver through PI3K/AKT pathway (decreased p } \\
\text { (Ser 307)-IRS-1 and increased the p (Ser } \\
347)-A K T \text { and p (Ser 9)-GSK3 } \beta \text { ), prevented } \\
\text { gluconeogenesis by enhancing the activity of } \\
\text { AMPK and inhibiting PEPCK and glucose } \\
\text { G6Pase protein expression. }\end{array}$ & [203] \\
\hline & $\mathrm{db} / \mathrm{db}$ mice & $25,50,100$, and $200 \mathrm{mg} / \mathrm{kg}$ (orally) & $\begin{array}{l}\text { Upregulated the expression of IRS-1, IDH2, and } \\
\text { G6PD2, and downregulated the expression of } \\
\text { the SOCS3. }\end{array}$ & [205] \\
\hline & $\begin{array}{l}\text { High fat diet and } \\
\text { streptozotocin-induced diabetic mice }\end{array}$ & $\begin{array}{l}100 \text { or } 200 \mathrm{mg} / \mathrm{kg} \text { for four } \\
\text { weeks (orally) }\end{array}$ & $\begin{array}{l}\text { Upregulated SOD2 and GSH-Px, suppressed the } \\
\text { serum level of MDA and NOX4. }\end{array}$ & [203] \\
\hline & Glucosamine-treated HepG2 cells & $20-80 \mu \mathrm{M}$ & $\begin{array}{l}\text { Increased the levels of SOD and GSH-Px, } \\
\text { decreased the MDA level and NOX4 protein } \\
\text { expression. }\end{array}$ & [203] \\
\hline & C57BL6/J mice fed with high fat diet & $200 \mathrm{mg} / \mathrm{kg}$ for $4-8$ weeks & $\begin{array}{l}\text { Increased skeletal muscle insulin sensitivity by } \\
\text { activating IRS-1/AKT/GLUT4. }\end{array}$ & [203] \\
\hline & $\mathrm{db} / \mathrm{db}$ mice & $200 \mathrm{mg} / \mathrm{kg}$ for 8 weeks & $\begin{array}{l}\text { Augmented myogenesis by increasing } \\
\text { expression of MyoD, MyoG and MHC } \\
\text { expressions }\end{array}$ & [204] \\
\hline & High glucose treated $\mathrm{C} 2 \mathrm{C} 12$ cells & $10,30,100 \mu \mathrm{M}$ for $24 \mathrm{~h}$ & $\begin{array}{l}\text { Increased MyoD and MyoG mRNA/ } \\
\text { protein levels. }\end{array}$ & [203] \\
\hline & Skeletal muscle of $\mathrm{db} / \mathrm{db}$ mice & $200 \mathrm{mg} / \mathrm{kg}$ /day for 8 weeks (orally) & $\begin{array}{l}\text { Increased number of mitochondria, } \\
\text { mitochondrial DNA levels, and expression of } \\
\text { genes involved in mitochondrial biogenesis. }\end{array}$ & [205] \\
\hline
\end{tabular}

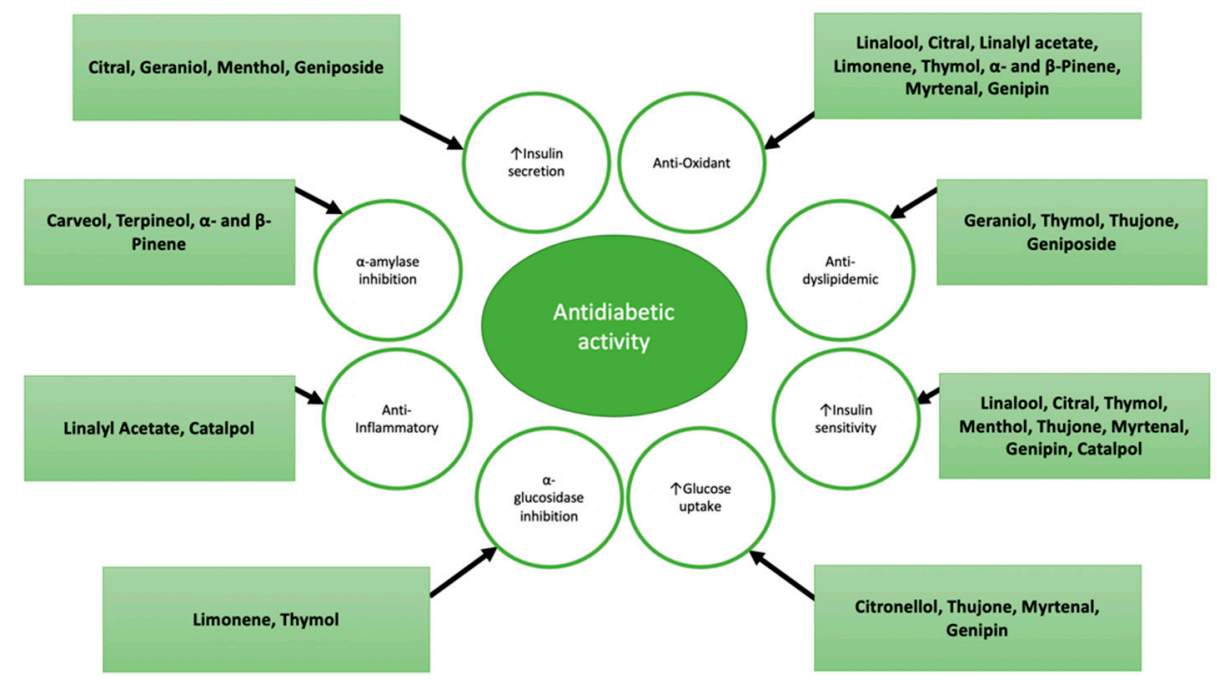

Figure 4. Mechanisms of action of different monoterpenes.

\section{Structure-Activity Relationship}

Although monoterpenes possess multiple pharmacological and molecular mechanisms of action, their structure-activity relationship has not been fully elucidated yet. In vitro and in vivo data summarized in this review demonstrate that there is a wide range of mechanisms of action by which monoterpenes exhibit their antidiabetic effects. These include (1) inhibition of $\alpha$-amylase and $\alpha$-glucosidase, (2) stimulation of insulin release, (3) stimulation of glucose uptake, (4) increase in insulin sensitivity, (5) inhibition of 
gluconeogenesis, (6) reduction in cellular oxidative stress, (7) reversal of dyslipidemia, (8) increase in anti-inflammatory activity, and (9) inhibition of pancreatic $\beta$-cell apoptosis. The current review discusses the antidiabetic effect of different monoterpenes using in vitro, as well as in vivo models, in which oxidative metabolism is an essential factor to consider. For example, $p$-cymene could be hydroxylated as a result of oxidative metabolism at a position comparable to the hydroxyl group position in $\alpha$-terpineol. Hydroxylation of $p$ cymene also leads to the biosynthesis of an entirely different monoterpene, namely thymol, in which the antioxidant and antidiabetic properties are attributed to the pharmacophore of the phenolic hydroxyl group in its chemical structure. Therefore, it could be highly anticipated that structural modification of the parent molecule ( $p$-cymene), such as the introduction of hydroxyl group, enhances its antioxidant activity. This is also applicable to other compounds, such as citral, which contains an aldehyde group. It is well-known that aldehydes are highly resistant to oxidative deterioration [208]. Citral has a high tendency to be oxidized and therefore, the aldehyde group could be easily converted to a carboxylic acid group. Such potential metabolism of the aldehyde group is also applicable to the compound myrtenal. Moreover, limonene is a precursor for carveol. Considering the carbon numbering relative to limonene, the presence of an oxygenated group at carbon- 6 conjugated to a double bond at carbon- 1 and an isopropenyl group at carbon- 4 were found to be the major chemical features relevant for activity and potency of carveol. For example, compared to limonene and other limonene derivatives, carveol significantly decreased lipopolysacharide (LPS)-induced nitric oxide (NO) production in murine macrophages. This anti-inflammatory activity was credited to the chemical features that are absent in other compounds [209]. Earlier studies have attributed the effect of monoterpenes to their volatility [11], hydrophobicity [210], and non-specific [211] and non-competitive [212] mechanisms of action. The lipophilic characteristic of the monoterpene skeleton combined with the nature of the functional group is essential for its activity. It has been proposed that the rank of activity is the greatest for aldehydes (e.g., citral), followed by alcohols (e.g., linalool and geraniol), followed by hydrocarbons (e.g., p-cymene and limonene). It should also be noted that some monoterpenes (e.g., catalpol) that exist in glycosylated form are very polar, which also affects their biological activity [213]. Compounds that contain phenolic groups are known to confer protection against the deleterious effects of free radicals both by absorbing or neutralizing free radicals and by augmenting endogenous antioxidants [214]. Additionally, studies have shown that the presence of a phenolic structural moiety displays potent antioxidant effects and/or direct radical scavenging that can account for the antidiabetic activity of monoterpenes. Thymol and 4-terpineol are typical examples that have been reported for their antihyperglycemic effects $[145,154]$. Supporting these findings, Zunino and Zygadlo (2004) concluded that most potent monoterpenes are those that are alcohols and phenols [215]. A study conducted by Javan and Javan (2014) evaluated the structure-radical scavenging activity of thymol derivatives. It was concluded that the presence of an unsaturated double bond is the main factor that determines the antioxidant and radical scavenging activity of the monoterpene derivatives [216]. Interestingly, it was shown that the incorporation of monoterpenes into other groups such as flavonoids augments their antioxidant effect [217]. Whether a monoterpene is a simple hydrocarbon (e.g., $p$-cymene and limonene), hydroxy derivative, or phenolic, a potential antidiabetic effect has been reported at low doses. However, due to the wide range of variations in experimental settings (e.g., range of concentrations tested, modes of drug administration, cell type, and animal models used), in addition to controversial in vitro and in vivo findings and their species dependency, direct comparison of in vitro and in vivo potency between the various subtypes of monoterpenes is difficult. In fact, more in vivo studies should be undertaken to confirm in vitro findings. Furthermore, a full-scale pharmacokinetic profiling is needed to interpret the inconsistency between results observed in in vitro and in vivo preclinical studies.

Based on the above, structure-activity relationship among monoterpenes can be made only when the effect of each compound (acyclic, monocyclic, and bicyclic) is investigated 
using a single target in vitro, in which pharmacokinetic profile (absorption, distribution, metabolism, and elimination) is excluded. In addition, an in silico molecular docking approach must be used to predict the molecular mechanism of action of each monoterpene on its potential target related to diabetes. Determination of the order of potency of the monoterpenes under standardized conditions, will help in correlating the activity with structural features to identify the relevant structural determinants of antidiabetic activity.

\section{Summary and Conclusions}

$\mathrm{DM}$ is a disease associated with high rates of morbidity and mortality and one of the leading causes of death in the world. The major complications associated with diabetes mellitus are classified as microvascular (including retinopathy, neuropathy, and nephropathy) and macrovascular (including cardiovascular myopathy and cerebrovascular diseases) [218,219]. Hyperglycemia plays an important role in the onset and development of these complications, mainly by generating reactive oxygen species (ROS) which causes lipid peroxidation and membrane damage. Cardiovascular (CV) risk factors such as obesity, hypertension, and dyslipidemia are common in patients with DM, placing them at increased risk for cardiac events. DM can be controlled by targeting multiple components like glucose transport, insulin signaling, insulin secretion, lipid regulation, inflammation, and oxidation. Despite the availability of different classes of antidiabetic agents, side effects like weight gain and hypoglycemia affect patients' adherence to therapy. Novel medicinal compounds can be synthesized and designed for the treatment of several diseases based on the chemical structure of these molecules. Monoterpenes are the main components of essential oils and have been recognized for their wide range of cellular and molecular activities that could potentially underlie their positive therapeutic index. Due to their abundance in occurrence, various biological activities, and high safety profile, monoterpenes became central for research and development around the globe. In this article, the pathogenesis of $\mathrm{DM}$ and the classes of antidiabetic agents used for the management of the disease were discussed. Moreover, we summarized the effects of selected acyclic, monocyclic, and bicyclic monoterpenes that are supposed to possess a potential role in the management of DM. Based on the fact that monoterpenes show structural complexity and diversity, comparison of the net antidiabetic effect between the three subcategories of monoterpenes cannot be made due to inconsistency in dose, duration, mode of drug administration, target tissue, and animal model used. To accurately determine which category of monoterpenes (acyclic, monocyclic, bicyclic) can exhibit the greatest antidiabetic effect, a comparison must be made using the exact same experimental conditions (concentration used, cell and tissue type targeted, etc.). However, based on extensive review of experimental studies, it has been proposed that the rank of activity is the greatest for aldehydes (e.g., the acyclic monoterpene citral), followed by alcohols (e.g., the acyclic monoterpenes linalool and geraniol), followed by hydrocarbons (e.g., the monocyclic monoterpenes p-cymene and limonene) [213]. Due to the fact that monoterpenes provide a promising area of research, further studies with regards to their structure-activity relationship as well as structural modification are crucial to maximize their therapeutic effects. Their use in combination with other monoterpenes or natural compounds should be carried out in the future to fill in the gaps. Additionally, more research is still needed to investigate the actions of these molecules on diabetic patients in order to confirm their therapeutic ability in controlling hyperglycemia and dyslipidemia caused by the disease.

Author Contributions: L.T.A.K. and M.M.; writing—original draft preparation, L.T.A.K. and M.M.; writing—review and editing, A.A.; writing—review and editing, K.I.; writing-review and editing, B.S.; writing-review and editing. All authors have read and agreed to the published version of the manuscript.

Funding: This research received no external funding.

Institutional Review Board Statement: Not applicable. 
Conflicts of Interest: The authors declare no conflict of interest.

\section{References}

1. American Diabetes Association. 4. Lifestyle Management: Standards of Medical Care in Diabetes-2018. Diabetes Care 2018, 41 (Suppl. 1), S38-S50. [CrossRef]

2. American Diabetes Association. Standards of medical care in diabetes-2014. Diabetes Care 2014, 37 (Suppl. 1), S14-S80. [CrossRef]

3. Adeghate, E. Diabetes mellitus-multifactorial in aetiology and global in prevalence. Arch. Physiol. Biochem. 2001, 109, 197-199. [CrossRef]

4. Chiefari, E.; Arcidiacono, B.; Foti, D.; Brunetti, A. Gestational diabetes mellitus: An updated overview. J. Endocrinol. Investig. 2017, 40, 899-909. [CrossRef] [PubMed]

5. Anik, A.; Catli, G.; Abaci, A.; Bober, E. Maturity-onset diabetes of the young (MODY): An update. J. Pediatr. Endocrinol. Metab. 2015, 28, 251-263. [CrossRef] [PubMed]

6. American Diabetes Association. Diagnosis and Classification of Diabetes Mellitus. Diabetes Care 2010, 33 (Suppl. 1), S62-S69.

7. Diabetes Control and Complications Trial Research Group. Effect of intensive diabetes treatment on the development and progression of long-term complications in adolescents with insulin-dependent diabetes mellitus: Diabetes Control and Complications Trial. J. Pediatr. 1994, 125, 177-188.

8. Ahmed, M.S.; Khan, A.U.; Kury, L.T.A.; Shah, F.A. Computational and Pharmacological Evaluation of Carveol for Antidiabetic Potential. Front. Pharmacol. 2020, 11, 919. [CrossRef] [PubMed]

9. Zielińska-Błajet, M.; Feder-Kubis, J. Monoterpenes and Their Derivatives-Recent Development in Biological and Medical Applications. Int. J. Mol. Sci. 2020, 21, 7078. [CrossRef]

10. Özbek, H.; Yilmaz, B. Anti-inflammatory and hypoglycemic activities of alpha-pinene. ACTA Pharm. Sci. 2017, 55, 7. [CrossRef]

11. Habtemariam, S. Antidiabetic Potential of Monoterpenes: A Case of Small Molecules Punching above Their Weight. Int. J. Mol. Sci. 2017, 19, 4. [CrossRef] [PubMed]

12. Salsali, A.; Nathan, M. A Review of Types 1 and 2 Diabetes Mellitus and Their Treatment with Insulin. Am. J. Ther. 2006, 13, 349-361. [CrossRef] [PubMed]

13. Urakami, T. Maturity-onset diabetes of the young (MODY): Current perspectives on diagnosis and treatment. Diabetes Metab. Syndr. Obes. 2019, 12, 1047-1056. [CrossRef]

14. Lin, X.; Xu, Y.; Pan, X.; Xu, J.; Ding, Y.; Sun, X.; Song, X.; Ren, Y.; Shan, P.F. Global, regional, and national burden and trend of diabetes in 195 countries and territories: An analysis from 1990 to 2025. Sci. Rep. 2020, 10, 14790. [CrossRef]

15. van Belle, T.L.; Coppieters, K.T.; von Herrath, M.G. Type 1 diabetes: Etiology, immunology, and therapeutic strategies. Physiol. Rev. 2011, 91, 79-118. [CrossRef] [PubMed]

16. Gillespie, K.M. Type 1 diabetes: Pathogenesis and prevention. CMAJ Can. Med. Assoc. J. J. L'association Med. Can. 2006, 175, 165-170. [CrossRef]

17. Gerich, J.E. Insulin-dependent diabetes mellitus: Pathophysiology. Mayo Clin. Proc. 1986, 61, 787-791. [CrossRef]

18. Chaudhury, A.; Duvoor, C.; Reddy Dendi, V.S.; Kraleti, S.; Chada, A.; Ravilla, R.; Marco, A.; Shekhawat, N.S.; Montales, M.T.; Kuriakose, K.; et al. Clinical Review of Antidiabetic Drugs: Implications for Type 2 Diabetes Mellitus Management. Front. Endocrinol. 2017, 8, 6. [CrossRef]

19. Goran, M.I.; Ball, G.D.; Cruz, M.L. Obesity and risk of type 2 diabetes and cardiovascular disease in children and adolescents. J. Clin. Endocrinol. Metab. 2003, 88, 1417-1427. [CrossRef]

20. Gilmartin, A.B.H.; Ural, S.H.; Repke, J.T. Gestational Diabetes Mellitus. Rev. Obstet. Gynecol. 2008, 1, $129-134$.

21. Amed, S.; Oram, R. Maturity-Onset Diabetes of the Young (MODY): Making the Right Diagnosis to Optimize Treatment. Can. J. Diabetes 2016, 40, 449-454. [CrossRef] [PubMed]

22. Czech, M.P. Insulin action and resistance in obesity and type 2 diabetes. Nat. Med. 2017, 23, 804-814. [CrossRef] [PubMed]

23. Weyer, C.; Bogardus, C.; Mott, D.M.; Pratley, R.E. The natural history of insulin secretory dysfunction and insulin resistance in the pathogenesis of type 2 diabetes mellitus. J. Clin. Investig. 1999, 104, 787-794. [CrossRef] [PubMed]

24. Stumvoll, M.; Goldstein, B.J.; van Haeften, T.W. Type 2 diabetes: Principles of pathogenesis and therapy. Lancet 2005, 365, 1333-1346. [CrossRef]

25. Chatterjee, S.; Khunti, K.; Davies, M.J. Type 2 diabetes. Lancet 2017, 389, 2239-2251. [CrossRef]

26. Nyenwe, E.A.; Kitabchi, A.E. The evolution of diabetic ketoacidosis: An update of its etiology, pathogenesis and management. Metab. Clin. Exp. 2016, 65, 507-521. [CrossRef]

27. Marín-Peñalver, J.J.; Martín-Timón, I.; Sevillano-Collantes, C.; del Cañizo-Gómez, F.J. Update on the treatment of type 2 diabetes mellitus. World J. Diabetes 2016, 7, 354-395. [CrossRef]

28. Weir, M.R. The kidney and type 2 diabetes mellitus: Therapeutic implications of SGLT2 inhibitors. Postgrad. Med. 2016, 128, 290-298. [CrossRef]

29. Cai, C.; Qian, L.; Jiang, S.; Sun, Y.; Wang, Q.; Ma, D.; Xiao, G.; Li, B.; Xie, S.; Gao, T.; et al. Loss-of-function myostatin mutation increases insulin sensitivity and browning of white fat in Meishan pigs. Oncotarget 2017, 8, 34911-34922. [CrossRef]

30. Nigro, E.; Scudiero, O.; Ludovica Monaco, M.; Polito, R.; Schettino, P.; Grandone, A.; Perrone, L.; Miraglia Del Giudice, E.; Daniele, A. Adiponectin profile and Irisin expression in Italian obese children: Association with insulin-resistance. Cytokine 2017, 94, 8-13. [CrossRef] 
31. Qiu, S.; Cai, X.; Yin, H.; Zugel, M.; Sun, Z.; Steinacker, J.M.; Schumann, U. Association between circulating irisin and insulin resistance in non-diabetic adults: A meta-analysis. Metab. Clin. Exp. 2016, 65, 825-834. [CrossRef]

32. Petersen, K.F.; Shulman, G.I. Cellular mechanism of insulin resistance in skeletal muscle. J. R. Soc. Med. 2002,95 (Suppl. 42 ), 8-13. [PubMed]

33. Petersen, K.F.; Shulman, G.I. Pathogenesis of skeletal muscle insulin resistance in type 2 diabetes mellitus. Am. J. Cardiol. 2002, 90, 11g-18g. [CrossRef]

34. Satoh, T. Molecular mechanisms for the regulation of insulin-stimulated glucose uptake by small guanosine triphosphatases in skeletal muscle and adipocytes. Int. J. Mol. Sci. 2014, 15, 18677-18692. [CrossRef]

35. Galicia-Garcia, U.; Benito-Vicente, A.; Jebari, S.; Larrea-Sebal, A.; Siddiqi, H.; Uribe, K.B.; Ostolaza, H.; Martín, C. Pathophysiology of Type 2 Diabetes Mellitus. Int. J. Mol. Sci. 2020, 21, 6275. [CrossRef] [PubMed]

36. Titchenell, P.M.; Lazar, M.A.; Birnbaum, M.J. Unraveling the Regulation of Hepatic Metabolism by Insulin. Trends Endocrinol. Metab. 2017, 28, 497-505. [CrossRef]

37. Cherrington, A.D.; Moore, M.C.; Sindelar, D.K.; Edgerton, D.S. Insulin action on the liver in vivo. Biochem. Soc. Trans. 2007, 35, 1171-1174. [CrossRef]

38. Edgerton, D.S.; Lautz, M.; Scott, M.; Everett, C.A.; Stettler, K.M.; Neal, D.W.; Chu, C.A.; Cherrington, A.D. Insulin's direct effects on the liver dominate the control of hepatic glucose production. J. Clin. Investig. 2006, 116, 521-527. [CrossRef]

39. Meshkani, R.; Adeli, K. Hepatic insulin resistance, metabolic syndrome and cardiovascular disease. Clin. Biochem. 2009, 42, 1331-1346. [CrossRef]

40. Leclercq, I.A.; Da Silva Morais, A.; Schroyen, B.; Van Hul, N.; Geerts, A. Insulin resistance in hepatocytes and sinusoidal liver cells: Mechanisms and consequences. J. Hepatol. 2007, 47, 142-156. [CrossRef]

41. Gastaldelli, A.; Gaggini, M.; DeFronzo, R.A. Role of Adipose Tissue Insulin Resistance in the Natural History of Type 2 Diabetes: Results From the San Antonio Metabolism Study. Diabetes 2017, 66, 815-822. [CrossRef]

42. Czech, M.P. Mechanisms of insulin resistance related to white, beige, and brown adipocytes. Mol. Metab. 2020, 34, 27-42 [CrossRef] [PubMed]

43. Coelho, M.; Oliveira, T.; Fernandes, R. Biochemistry of adipose tissue: An endocrine organ. Arch. Med. Sci. 2013, 9, 191-200. [CrossRef] [PubMed]

44. Rosen, E.D.; Spiegelman, B.M. Adipocytes as regulators of energy balance and glucose homeostasis. Nature 2006, 444, 847-853. [CrossRef]

45. Scherer, P.E. The many secret lives of adipocytes: Implications for diabetes. Diabetologia 2019, 62, 223-232. [CrossRef] [PubMed]

46. Roden, M.; Shulman, G.I. The integrative biology of type 2 diabetes. Nature 2019, 576, 51-60. [CrossRef] [PubMed]

47. Maki, K.C.; Kelley, K.M.; Lawless, A.L.; Hubacher, R.L.; Schild, A.L.; Dicklin, M.R.; Rains, T.M. Validation of insulin sensitivity and secretion indices derived from the liquid meal tolerance test. Diabetes Technol. Ther. 2011, 13, 661-666. [CrossRef]

48. Meier, J.J.; Nauck, M.A. Is the diminished incretin effect in type 2 diabetes just an epi-phenomenon of impaired beta-cell function? Diabetes 2010, 59, 1117-1125. [CrossRef]

49. Surampudi, P.N.; John-Kalarickal, J.; Fonseca, V.A. Emerging concepts in the pathophysiology of type 2 diabetes mellitus. Mt. Sinai. J. Med. 2009, 76, 216-226. [CrossRef] [PubMed]

50. Baggio, L.L.; Drucker, D.J. Biology of incretins: GLP-1 and GIP. Gastroenterology 2007, 132, 2131-2157. [CrossRef]

51. Inzucchi, S.E.; Bergenstal, R.M.; Buse, J.B.; Diamant, M.; Ferrannini, E.; Nauck, M.; Peters, A.L.; Tsapas, A.; Wender, R.; Matthews, D.R. Management of hyperglycemia in type 2 diabetes, 2015: A patient-centered approach: Update to a position statement of the American Diabetes Association and the European Association for the Study of Diabetes. Diabetes Care 2015, 38, 140-149. [CrossRef] [PubMed]

52. Nauck, M.A.; Homberger, E.; Siegel, E.G.; Allen, R.C.; Eaton, R.P.; Ebert, R.; Creutzfeldt, W. Incretin effects of increasing glucose loads in man calculated from venous insulin and C-peptide responses. J. Clin. Endocrinol. Metab. 1986, 63, 492-498. [CrossRef]

53. Nauck, M.; Stöckmann, F.; Ebert, R.; Creutzfeldt, W. Reduced incretin effect in type 2 (non-insulin-dependent) diabetes. Diabetologia 1986, 29, 46-52. [CrossRef] [PubMed]

54. Drucker, D.J. Enhancing incretin action for the treatment of type 2 diabetes. Diabetes Care 2003, 26, 2929-2940. [CrossRef] [PubMed]

55. Drucker, D.J. Glucagon-like peptide-1 and the islet beta-cell: Augmentation of cell proliferation and inhibition of apoptosis Endocrinology 2003, 144, 5145-5148. [CrossRef] [PubMed]

56. Buteau, J. GLP-1 receptor signaling: Effects on pancreatic beta-cell proliferation and survival. Diabetes Metab. 2008, 34 (Suppl. 2), S73-S77. [CrossRef]

57. Gautier, J.F.; Fetita, S.; Sobngwi, E.; Salaun-Martin, C. Biological actions of the incretins GIP and GLP-1 and therapeutic perspectives in patients with type 2 diabetes. Diabetes Metab. 2005, 31, 233-242. [CrossRef]

58. Irwin, N.; Hunter, K.; Frizzell, N.; Flatt, P.R. Antidiabetic effects of sub-chronic activation of the GIP receptor alone and in combination with background exendin-4 therapy in high fat fed mice. Regul. Pept. 2009, 153, 70-76. [CrossRef]

59. Cao, L.; Li, D.; Feng, P.; Li, L.; Xue, G.F.; Li, G.; Holscher, C. A novel dual GLP-1 and GIP incretin receptor agonist is neuroprotective in a mouse model of Parkinson's disease by reducing chronic inflammation in the brain. Neuroreport 2016, 27, 384-391. [CrossRef]

60. Boer, G.A.; Holst, J.J. Incretin Hormones and Type 2 Diabetes-Mechanistic Insights and Therapeutic Approaches. Biology 2020, 9, 473. [CrossRef] 
61. Toft-Nielsen, M.B.; Damholt, M.B.; Madsbad, S.; Hilsted, L.M.; Hughes, T.E.; Michelsen, B.K.; Holst, J.J. Determinants of the impaired secretion of glucagon-like peptide-1 in type 2 diabetic patients. J. Clin. Endocrinol. Metab. 2001, 86, 3717-3723. [CrossRef] [PubMed]

62. Faerch, K.; Vaag, A.; Holst, J.J.; Glümer, C.; Pedersen, O.; Borch-Johnsen, K. Impaired fasting glycaemia vs impaired glucose tolerance: Similar impairment of pancreatic alpha and beta cell function but differential roles of incretin hormones and insulin action. Diabetologia 2008, 51, 853-861. [CrossRef] [PubMed]

63. Nauck, M.A.; Meier, J.J. The incretin effect in healthy individuals and those with type 2 diabetes: Physiology, pathophysiology, and response to therapeutic interventions. Lancet Diabetes Endocrinol. 2016, 4, 525-536. [CrossRef]

64. Lynn, F.C.; Thompson, S.A.; Pospisilik, J.A.; Ehses, J.A.; Hinke, S.A.; Pamir, N.; McIntosh, C.H.; Pederson, R.A. A novel pathway for regulation of glucose-dependent insulinotropic polypeptide (GIP) receptor expression in beta cells. FASEB J. Off. Publ. Fed. Am. Soc. Exp. Biol. 2003, 17, 91-93.

65. Lynn, F.C.; Pamir, N.; Ng, E.H.; McIntosh, C.H.; Kieffer, T.J.; Pederson, R.A. Defective glucose-dependent insulinotropic polypeptide receptor expression in diabetic fatty Zucker rats. Diabetes 2001, 50, 1004-1011. [CrossRef] [PubMed]

66. Balakumar, P.; Maung, U.K.; Jagadeesh, G. Prevalence and prevention of cardiovascular disease and diabetes mellitus. Pharmacol. Res. 2016, 113, 600-609. [CrossRef]

67. Von Ah Morano, A.E.; Dorneles, G.P.; Peres, A.; Lira, F.S. The role of glucose homeostasis on immune function in response to exercise: The impact of low or higher energetic conditions. J. Cell Physiol. 2020, 235, 3169-3188. [CrossRef]

68. Deed, G.; Barlow, J.; Kawol, D.; Kilov, G.; Sharma, A.; Hwa, L.Y. Diet and diabetes. Aust. Fam. Phys. 2015, $44,192-196$.

69. Tuso, P. Prediabetes and lifestyle modification: Time to prevent a preventable disease. Perm. J. 2014, 18, 88-93. [CrossRef]

70. Thent, Z.C.; Das, S.; Henry, L.J. Role of Exercise in the Management of Diabetes Mellitus: The Global Scenario. PLoS ONE 2013, $8, \mathrm{e} 80436$.

71. Knowler, W.C.; Barrett-Connor, E.; Fowler, S.E.; Hamman, R.F.; Lachin, J.M.; Walker, E.A.; Nathan, D.M. Reduction in the incidence of type 2 diabetes with lifestyle intervention or metformin. N. Engl. J. Med. 2002, 346, 393-403. [PubMed]

72. Pan, X.R.; Li, G.W.; Hu, Y.H.; Wang, J.X.; Yang, W.Y.; An, Z.X.; Hu, Z.X.; Lin, J.; Xiao, J.Z.; Cao, H.B.; et al. Effects of diet and exercise in preventing NIDDM in people with impaired glucose tolerance. The Da Qing IGT and Diabetes Study. Diabetes Care 1997, 20, 537-544. [CrossRef] [PubMed]

73. Olokoba, A.B.; Obateru, O.A.; Olokoba, L.B. Type 2 Diabetes Mellitus: A Review of Current Trends. Oman. Med. J. 2012, 27, 269-273. [CrossRef] [PubMed]

74. Tran, L.; Zielinski, A.; Roach, A.H.; Jende, J.A.; Householder, A.M.; Cole, E.E.; Atway, S.A.; Amornyard, M.; Accursi, M.L.; Shieh, S.W.; et al. Pharmacologic treatment of type 2 diabetes: Oral medications. Ann. Pharmacother. 2015, 49, 540-556. [CrossRef] [PubMed]

75. Song, R. Mechanism of Metformin: A Tale of Two Sites. Diabetes Care 2016, 39, 187-189. [CrossRef] [PubMed]

76. Shin, N.R.; Lee, J.C.; Lee, H.Y.; Kim, M.S.; Whon, T.W.; Lee, M.S.; Bae, J.W. An increase in the Akkermansia spp. population induced by metformin treatment improves glucose homeostasis in diet-induced obese mice. Gut 2014, 63, 727-735. [CrossRef]

77. Wen, S.; Wang, C.; Gong, M.; Zhou, L. An overview of energy and metabolic regulation. Sci. China. Life Sci. 2019, 62, 771-790. [CrossRef]

78. Viollet, B.; Guigas, B.; Sanz Garcia, N.; Leclerc, J.; Foretz, M.; Andreelli, F. Cellular and molecular mechanisms of metformin: An overview. Clin. Sci. (Lond.) 2012, 122, 253-270. [CrossRef]

79. Proks, P.; Reimann, F.; Green, N.; Gribble, F.; Ashcroft, F. Sulfonylurea stimulation of insulin secretion. Diabetes 2002, 51 (Suppl. 3), S368-S376. [CrossRef]

80. Holman, R.R.; Paul, S.K.; Bethel, M.A.; Matthews, D.R.; Neil, H.A. 10-year follow-up of intensive glucose control in type 2 diabetes. N. Engl. J. Med. 2008, 359, 1577-1589. [CrossRef]

81. Becker, M.; Galler, A.; Raile, K. Meglitinide analogues in adolescent patients with HNF1A-MODY (MODY 3). Pediatrics 2014, 133, e775-e779. [CrossRef] [PubMed]

82. Skliros, N.P.; Vlachopoulos, C.; Tousoulis, D. Treatment of diabetes: Crossing to the other side. Hell. J. Cardiol. HJC Hell. Kardiol. Ep. 2016, 57, 304-310. [CrossRef]

83. Jung, Y.; Cao, Y.; Paudel, S.; Yoon, G.; Cheon, S.H.; Bae, G.U.; Jin, L.T.; Kim, Y.K.; Kim, S.N. Antidiabetic effect of SN158 through PPARalpha/gamma dual activation in ob/ob mice. Chem.-Biol. Interact. 2017, 268, 24-30. [CrossRef] [PubMed]

84. Gopal, S.S.; Lakshmi, M.J.; Sharavana, G.; Sathaiah, G.; Sreerama, Y.N.; Baskaran, V. Lactucaxanthin-a potential anti-diabetic carotenoid from lettuce (Lactuca sativa) inhibits alpha-amylase and alpha-glucosidase activity in vitro and in diabetic rats. Food Funct. 2017, 8, 1124-1131. [CrossRef] [PubMed]

85. Ishii, H.; Hayashino, Y.; Akai, Y.; Yabuta, M.; Tsujii, S. Dipeptidyl peptidase-4 inhibitors as preferable oral hypoglycemic agents in terms of treatment satisfaction: Results from a multicenter, 12-week, open label, randomized controlled study in Japan. J. Diabetes Investig. 2017, 9, 137-145. [CrossRef]

86. Kobayashi, K.; Yokoh, H.; Sato, Y.; Takemoto, M.; Uchida, D.; Kanatsuka, A.; Kuribayashi, N.; Terano, T.; Hashimoto, N.; Sakurai, K.; et al. Efficacy and safety of the dipeptidyl peptidase- 4 inhibitor sitagliptin compared with alpha-glucosidase inhibitor in Japanese patients with type 2 diabetes inadequately controlled on sulfonylurea alone (SUCCESS-2): A multicenter, randomized, open-label, non-inferiority trial. Diabetes Obes. Metab. 2014, 16, 761-765. [PubMed] 
87. Deacon, C.F.; Mannucci, E.; Ahren, B. Glycaemic efficacy of glucagon-like peptide-1 receptor agonists and dipeptidyl peptidase-4 inhibitors as add-on therapy to metformin in subjects with type 2 diabetes-a review and meta analysis. Diabetes Obes. Metab. 2012, 14, 762-767. [CrossRef]

88. Zhou, M.; Mok, M.T.; Sun, H.; Chan, A.W.; Huang, Y.; Cheng, A.S.; Xu, G. The anti-diabetic drug exenatide, a glucagonlike peptide-1 receptor agonist, counteracts hepatocarcinogenesis through cAMP-PKA-EGFR-STAT3 axis. Oncogene 2017, 36, 4135-4149. [CrossRef]

89. Liu, J.; Hu, Y.; Zhang, H.; Xu, Y.; Wang, G. Exenatide treatment increases serum irisin levels in patients with obesity and newly diagnosed type 2 diabetes. J. Diabetes Its Complicat. 2016, 30, 1555-1559. [CrossRef]

90. Seino, Y.; Fukushima, M.; Yabe, D. GIP and GLP-1, the two incretin hormones: Similarities and differences. J. Diabetes Investig. 2010, 1, 8-23. [CrossRef]

91. Ojha, A.; Ojha, U.; Mohammed, R.; Chandrashekar, A.; Ojha, H. Current perspective on the role of insulin and glucagon in the pathogenesis and treatment of type 2 diabetes mellitus. Clin. Pharmacol. 2019, 11, 57-65. [CrossRef]

92. Adeghate, E.; Mohsin, S.; Adi, F.; Ahmed, F.; Yahya, A.; Kalász, H.; Tekes, K.; Adeghate, E.A. An update of SGLT1 and SGLT2 inhibitors in early phase diabetes-type 2 clinical trials. Expert Opin. Investig. Drugs 2019, 28, 811-820. [CrossRef] [PubMed]

93. Steen, O.; Goldenberg, R.M. The Role of Sodium-Glucose Cotransporter 2 Inhibitors in the Management of Type 2 Diabetes. Can. J. Diabetes 2017, 41, 517-523. [CrossRef] [PubMed]

94. Nauck, M.A. Update on developments with SGLT2 inhibitors in the management of type 2 diabetes. Drug Des. Dev. Ther. 2014, 8 , 1335-1380. [CrossRef] [PubMed]

95. Kosiborod, M.; Gause-Nilsson, I.; Xu, J.; Sonesson, C.; Johnsson, E. Efficacy and safety of dapagliflozin in patients with type 2 diabetes and concomitant heart failure. J. Diabetes Its Complicat. 2017, 31, 1215-1221. [CrossRef]

96. Bailey, C.J.; Gross, J.L.; Hennicken, D.; Iqbal, N.; Mansfield, T.A.; List, J.F. Dapagliflozin add-on to metformin in type 2 diabetes inadequately controlled with metformin: A randomized, double-blind, placebo-controlled 102-week trial. BMC Med. 2013, 11, 43. [CrossRef]

97. Brahmkshatriya, P.P.; Brahmkshatriya, P.S. Terpenes: Chemistry, Biological Role, and Therapeutic Applications. In Natural Products: Phytochemistry, Botany and Metabolism of Alkaloids, Phenolics and Terpenes; Ramawat, K.G., Mérillon, J.-M., Eds.; Springer: Berlin/Heidelberg, Germany, 2013; pp. 2665-2691.

98. Tan, X.C.; Chua, K.H.; Ravishankar Ram, M.; Kuppusamy, U.R. Monoterpenes: Novel insights into their biological effects and roles on glucose uptake and lipid metabolism in 3T3-L1 adipocytes. Food Chem. 2016, 196, 242-250. [CrossRef]

99. Guimarães, A.C.; Meireles, L.M.; Lemos, M.F.; Guimarães, M.C.C.; Endringer, D.C.; Fronza, M.; Scherer, R. Antibacterial Activity of Terpenes and Terpenoids Present in Essential Oils. Molecules 2019, 24, 2471. [CrossRef]

100. Kozioł, A.; Stryjewska, A.; Librowski, T.; Sałat, K.; Gaweł, M.; Moniczewski, A.; Lochyński, S. An overview of the pharmacological properties and potential applications of natural monoterpenes. Mini. Rev. Med. Chem. 2014, 14, 1156-1168. [CrossRef]

101. Ke, J.; Zhu, C.; Zhang, Y.; Zhang, W. Anti-Arrhythmic Effects of Linalool via Cx43 Expression in a Rat Model of Myocardial Infarction. Front. Pharmacol. 2020, 11, 926. [CrossRef]

102. Pripdeevech, P.; Machan, T. Fingerprint of volatile flavour constituents and antioxidant activities of teas from Thailand. Food Chem. 2011, 125, 797-802. [CrossRef]

103. Sajid, M.; Khan, M.R.; Ismail, H.; Latif, S.; Rahim, A.A.; Mehboob, R.; Shah, S.A. Antidiabetic and antioxidant potential of Alnus nitida leaves in alloxan induced diabetic rats. J. Ethnopharmacol. 2020, 251, 112544. [CrossRef] [PubMed]

104. Peana, A.T.; D'Aquila, P.S.; Panin, F.; Serra, G.; Pippia, P.; Moretti, M.D. Anti-inflammatory activity of linalool and linalyl acetate constituents of essential oils. Phytomed. Int. J. Phytother. Phytopharm. 2002, 9, 721-726. [CrossRef] [PubMed]

105. More, T.; Kulkarni, B.; Nalawade, M.; Arvindekar, A. Antidiabetic activity of linalool and limonene in streptozotocin-induced diabetic rat: A combinatorial therapy approach. Int. J. Pharm. Pharm. Sci. 2014, 6, 159-163.

106. Garba, H.A.; Mohammed, A.; Ibrahim, M.A.; Shuaibu, M.N. Effect of lemongrass (Cymbopogon citratus Stapf) tea in a type 2 diabetes rat model. Clin. Phytosci. 2020, 6, 19. [CrossRef]

107. Kwon, Y.I.; Apostolidis, E.; Shetty, K. Evaluation of pepper (Capsicum annuum) for management of diabetes and hypertension. J. Food Biochem. 2007, 31, 370-385. [CrossRef]

108. Boaduo, N.K.; Katerere, D.; Eloff, J.N.; Naidoo, V. Evaluation of six plant species used traditionally in the treatment and control of diabetes mellitus in South Africa using in vitro methods. Pharm. Biol. 2014, 52, 756-761. [CrossRef] [PubMed]

109. Jumepaeng, T.; Prachakool, S.; Luthria, D.L.; Chanthai, S. Determination of antioxidant capacity and $\alpha$-amylase inhibitory activity of the essential oils from citronella grass and lemongrass. Int. Food Res. J. 2013, 20, 481-485.

110. Deepa, B.; Venkataraman, A. Linalool, a plant derived monoterpene alcohol, rescues kidney from diabetes-induced nephropathic changes via blood glucose reduction. Diabetol. Croat. 2011, 40, 121-137.

111. Shah, G.; Shri, R.; Panchal, V.; Sharma, N.; Singh, B.; Mann, A.S. Scientific basis for the therapeutic use of Cymbopogon citratus, stapf (Lemon grass). J. Adv. Pharm. Technol. Res. 2011, 2, 3-8. [CrossRef]

112. Najafian, M.; Ebrahim-Habibi, A.; Yaghmaei, P.; Parivar, K.; Larijani, B. Citral as a potential antihyperlipidemic medicine in diabetes: A study on streptozotocin-induced diabetic rats. Iran. J. Diabetes Lipid Disord. 2011, 10, 3.

113. Molinaro, A.; Wahlström, A.; Marschall, H.U. Role of Bile Acids in Metabolic Control. Trends Endocrinol. Metab. 2018, 29 , 31-41. [CrossRef] [PubMed] 
114. Schaap, F.G.; Trauner, M.; Jansen, P.L. Bile acid receptors as targets for drug development. Nat. Rev. Gastroenterol. Hepatol. 2014, 11, 55-67. [CrossRef] [PubMed]

115. Ooi, C.P.; Loke, S.C. Colesevelam for type 2 diabetes mellitus. Cochrane Database Syst. Rev. 2012, 12, Cd009361. [CrossRef] [PubMed]

116. Zieve, F.J.; Kalin, M.F.; Schwartz, S.L.; Jones, M.R.; Bailey, W.L. Results of the glucose-lowering effect of WelChol study (GLOWS): A randomized, double-blind, placebo-controlled pilot study evaluating the effect of colesevelam hydrochloride on glycemic control in subjects with type 2 diabetes. Clin. Ther. 2007, 29, 74-83. [CrossRef]

117. Damci, T.; Tatliagac, S.; Osar, Z.; Ilkova, H. Fenofibrate treatment is associated with better glycemic control and lower serum leptin and insulin levels in type 2 diabetic patients with hypertriglyceridemia. Eur. J. Intern. Med. 2003, 14, 357-360. [CrossRef]

118. Nozue, T.; Michishita, I.; Mizuguchi, I. Effects of ezetimibe on glucose metabolism in patients with type 2 diabetes: A 12-week, open-label, uncontrolled, pilot study. Curr. Ther. Res. Clin. Exp. 2010, 71, 252-258. [CrossRef]

119. Modak, T.; Mukhopadhaya, A. Effects of citral, a naturally occurring antiadipogenic molecule, on an energy-intense diet model of obesity. Indian J. Pharmacol. 2011, 43, 300-305. [CrossRef] [PubMed]

120. Mishra, C.; Khalid, M.A.; Fatima, N.; Singh, B.; Tripathi, D.; Waseem, M.; Mahdi, A.A. Effects of citral on oxidative stress and hepatic key enzymes of glucose metabolism in streptozotocin/high-fat-diet induced diabetic dyslipidemic rats. Iran. J. Basic Med. Sci. 2019, 22, 49-57.

121. Lei, Y.; Fu, P.; Jun, X.; Cheng, P. Pharmacological Properties of Geraniol-A Review. Planta Med. 2019, 85, 48-55. [CrossRef]

122. Babukumar, S.; Vinothkumar, V.; Sankaranarayanan, C.; Srinivasan, S. Geraniol, a natural monoterpene, ameliorates hyperglycemia by attenuating the key enzymes of carbohydrate metabolism in streptozotocin-induced diabetic rats. Pharm. Biol. 2017, 55, 1442-1449. [CrossRef]

123. Kamble, S.P.; Ghadyale, V.A.; Patil, R.S.; Haldavnekar, V.S.; Arvindekar, A.U. Inhibition of GLUT2 transporter by geraniol from Cymbopogon martinii: A novel treatment for diabetes mellitus in streptozotocin-induced diabetic rats. J. Pharm. Pharmacol. 2020, 72, 294-304. [CrossRef] [PubMed]

124. Srinivasan, S.; Muruganathan, U. Antidiabetic efficacy of citronellol, a citrus monoterpene by ameliorating the hepatic key enzymes of carbohydrate metabolism in streptozotocin-induced diabetic rats. Chem.-Biol. Interact. 2016, 250, 38-46. [CrossRef] [PubMed]

125. De Toledo, L.G.; Ramos, M.A.; Spósito, L.; Castilho, E.M.; Pavan, F.R.; Lopes Éde, O.; Zocolo, G.J.; Silva, F.A.; Soares, T.H.; Dos Santos, A.G.; et al. Essential Oil of Cymbopogon nardus (L.) Rendle: A Strategy to Combat Fungal Infections Caused by Candida Species. Int. J. Mol. Sci. 2016, 17, 1252. [CrossRef] [PubMed]

126. Abena, A.A.; Gbenou, J.D.; Yayi, E.; Moudachirou, M.; Ongoka, R.P.; Ouamba, J.M.; Silou, T. Comparative chemical and analgesic properties of essential oils of Cymbopogon nardus (L) Rendle of Benin and Congo. Afr. J. Tradit. Complement. Altern. Med. 2007, 4 267-272. [CrossRef]

127. Boukhris, M.; Bouaziz, M.; Feki, I.; Jemai, H.; El Feki, A.; Sayadi, S. Hypoglycemic and antioxidant effects of leaf essential oil of Pelargonium graveolens L'Hér. in alloxan induced diabetic rats. Lipids Health Dis. 2012, 11, 81. [CrossRef] [PubMed]

128. Santos, M.; Moreira, F.; Fraga, B.; Sousa, D.; Bonjardim, L.; Quintans-Júnior, L. Cardiovascular effects of monoterpenes: A review. Rev. Bras. Farmacogn. 2011, 21, 764-771. [CrossRef]

129. Buchbauer, G.; Jirovetz, L.; Jäger, W.; Dietrich, H.; Plank, C. Aromatherapy: Evidence for sedative effects of the essential oil of lavender after inhalation. Z. Für Nat. C 1991, 46, 1067-1072. [CrossRef]

130. Dzumayev, K.; Tsibulskaya, I.; Zenkevich, I.; Tkachenko, K.; Satzyperova, I. Essential Oils of Salvia sclarea L. Produced from Plants Grown in Southern Uzbekistan. J. Essent. Oil Res. 1995, 7, 597-604. [CrossRef]

131. Yang, H.J.; Kim, K.Y.; Kang, P.; Lee, H.S.; Seol, G.H. Effects of Salvia sclarea on chronic immobilization stress induced endothelial dysfunction in rats. BMC Complement. Altern. Med. 2014, 14, 396. [CrossRef]

132. Shin, Y.K.; Hsieh, Y.S.; Kwon, S.; Lee, H.S.; Seol, G.H. Linalyl acetate restores endothelial dysfunction and hemodynamic alterations in diabetic rats exposed to chronic immobilization stress. J. Appl. Physiol. (Bethesda Md. 1985) 2018, 124, 1274-1283. [CrossRef] [PubMed]

133. Sun, J. D-Limonene: Safety and clinical applications. Altern. Med. Rev. 2007, 12, 259-264. [PubMed]

134. Bacanlı, M.; Anlar, H.G.; Aydın, S.; Çal, T.; Arı, N.; Ündeğer Bucurgat, Ü.; Başaran, A.A.; Başaran, N. D-limonene ameliorates diabetes and its complications in streptozotocin-induced diabetic rats. Food Chem. Toxicol. Int. J. Publ. Br. Ind. Biol. Res. Assoc. 2017, 110, 434-442. [CrossRef] [PubMed]

135. Joglekar, M.M.; Panaskar, S.N.; Chougale, A.D.; Kulkarni, M.J.; Arvindekar, A.U. A novel mechanism for antiglycative action of limonene through stabilization of protein conformation. Mol. Biosyst. 2013, 9, 2463-2472. [CrossRef]

136. Murali, R.; Saravanan, R. Antidiabetic effect of d-limonene, a monoterpene in streptozotocin-induced diabetic rats. Biomed. Prev. Nutr. 2012, 2, 269-275. [CrossRef]

137. Bossou, A.D.; Mangelinckx, S.; Yedomonhan, H.; Boko, P.M.; Akogbeto, M.C.; De Kimpe, N.; Avlessi, F.; Sohounhloue, D.C. Chemical composition and insecticidal activity of plant essential oils from Benin against Anopheles gambiae (Giles). Parasit Vectors 2013, 6, 337. [CrossRef]

138. Liu, P.; Liu, X.C.; Dong, H.W.; Liu, Z.L.; Du, S.S.; Deng, Z.W. Chemical composition and insecticidal activity of the essential oil of Illicium pachyphyllum fruits against two grain storage insects. Molecules 2012, 17, 14870-14881. [CrossRef] 
139. Fang, R.; Jiang, C.H.; Wang, X.Y.; Zhang, H.M.; Liu, Z.L.; Zhou, L.; Du, S.S.; Deng, Z.W. Insecticidal activity of essential oil of Carum Carvi fruits from China and its main components against two grain storage insects. Molecules 2010, 15, 9391-9402. [CrossRef]

140. Bhatia, S.P.; McGinty, D.; Letizia, C.S.; Api, A.M. Fragrance material review on carveol. Food Chem. Toxicol. Int. J. Publ. Br. Ind. Biol. Res. Assoc. 2008, 46 (Suppl. 11), S85-S87. [CrossRef]

141. Wagner, K.H.; Elmadfa, I. Biological relevance of terpenoids. Overview focusing on mono-, di- and tetraterpenes. Ann. Nutr. Metab. 2003, 47, 95-106. [CrossRef]

142. Marques, F.M.; Figueira, M.M.; Schmitt, E.F.P.; Kondratyuk, T.P.; Endringer, D.C.; Scherer, R.; Fronza, M. In vitro anti-inflammatory activity of terpenes via suppression of superoxide and nitric oxide generation and the NF- $\mathrm{kB}$ signalling pathway. Inflammopharmacology 2019, 27, 281-289. [CrossRef] [PubMed]

143. Rossi, Y.E.; Palacios, S.M. Fumigant toxicity of Citrus sinensis essential oil on Musca domestica L. adults in the absence and presence of a P450 inhibitor. Acta Trop. 2013, 127, 33-37. [CrossRef] [PubMed]

144. Sales, A.; Felipe, L.; Bicas, J. Production, Properties, and Applications of $\alpha$-Terpineol. Food Bioprocess Technol. 2020, 13, 1261-1279. [CrossRef]

145. Capetti, F.; Cagliero, C.; Marengo, A.; Bicchi, C.; Rubiolo, P.; Sgorbini, B. Bio-Guided Fractionation Driven by In Vitro $\alpha$-Amylase Inhibition Assays of Essential Oils Bearing Specialized Metabolites with Potential Hypoglycemic Activity. Plants 2020, $9,1242$. [CrossRef]

146. Sousa, G.M.; Cazarin, C.B.B.; Maróstica Junior, M.R.; Lamas, C.A.; Quitete, V.; Pastore, G.M.; Bicas, J.L. The effect of $\alpha$-terpineol enantiomers on biomarkers of rats fed a high-fat diet. Heliyon 2020, 6, e03752. [CrossRef]

147. Bouyahya, A.; Chamkhi, I.; Guaouguaou, F.E.; Benali, T.; Balahbib, A.; El Omari, N.; Taha, D.; El-Shazly, M.; El Menyiy, N. Ethnomedicinal use, phytochemistry, pharmacology, and food benefits of Thymus capitatus. J. Ethnopharmacol. 2020, $259,112925$. [CrossRef]

148. Abbasi, S.; Gharaghani, S.; Benvidi, A.; Rezaeinasab, M. New insights into the efficiency of thymol synergistic effect with p-cymene in inhibiting advanced glycation end products: A multi-way analysis based on spectroscopic and electrochemical methods in combination with molecular docking study. J. Pharm. Biomed. Anal. 2018, 150, 436-451. [CrossRef]

149. Miladi, H.; Zmantar, T.; Kouidhi, B.; Chaabouni, Y.; Mahdouani, K.; Bakhrouf, A.; Chaieb, K. Use of carvacrol, thymol, and eugenol for biofilm eradication and resistance modifying susceptibility of Salmonella enterica serovar Typhimurium strains to nalidixic acid. Microb. Pathog. 2017, 104, 56-63. [CrossRef]

150. Veras, H.N.; Araruna, M.K.; Costa, J.G.; Coutinho, H.D.; Kerntopf, M.R.; Botelho, M.A.; Menezes, I.R. Topical antiinflammatory activity of essential oil of Lippia sidoides cham: Possible mechanism of action. Phytother. Res. PTR 2013, 27, 179-185. [CrossRef]

151. Kang, S.H.; Kim, Y.S.; Kim, E.K.; Hwang, J.W.; Jeong, J.H.; Dong, X.; Lee, J.W.; Moon, S.H.; Jeon, B.T.; Park, P.J. Anticancer Effect of Thymol on AGS Human Gastric Carcinoma Cells. J. Microbiol. Biotechnol. 2016, 26, 28-37. [CrossRef]

152. Haque, M.R.; Ansari, S.H.; Najmi, A.K.; Ahmad, M.A. Monoterpene phenolic compound thymol prevents high fat diet induced obesity in murine model. Toxicol. Mech. Methods 2014, 24, 116-123. [CrossRef] [PubMed]

153. Fang, F.; Li, H.; Qin, T.; Li, M.; Ma, S. Thymol improves high-fat diet-induced cognitive deficits in mice via ameliorating brain insulin resistance and upregulating NRF2/HO-1 pathway. Metab. Brain Dis. 2017, 32, 385-393. [CrossRef] [PubMed]

154. Saravanan, S.; Pari, L. Role of thymol on hyperglycemia and hyperlipidemia in high fat diet-induced type 2 diabetic C57BL/6J mice. Eur. J. Pharmacol. 2015, 761, 279-287. [CrossRef] [PubMed]

155. Homocysteine Lowering Trialists Collaboration. Dose-dependent effects of folic acid on blood concentrations of homocysteine: A meta-analysis of the randomized trials. Am. J. Clin. Nutr. 2005, 82, 806-812. [CrossRef]

156. Saravanan, S.; Pari, L. Protective effect of thymol on high fat diet induced diabetic nephropathy in C57BL/6J mice. Chem.-Biol. Interact. 2016, 245, 1-11. [CrossRef]

157. Oskouei, B.G.; Abbaspour-Ravasjani, S.; Jamal Musavinejad, S.; Ahmad Salehzadeh, S.; Abdolhosseinzadeh, A.; Hamishehkar, H.; Ghahremanzadeh, K.; Shokouhi, B. In vivo Evaluation of Anti-Hyperglycemic, Anti-hyperlipidemic and Anti-Oxidant Status of Liver and Kidney of Thymol in STZ-Induced Diabetic Rats. Drug Res. 2019, 69, 46-52. [CrossRef]

158. Hyun, T.K.; Kim, H.-C.; Kim, J.-S. Antioxidant and antidiabetic activity of Thymus quinquecostatus Celak. Ind. Crops Prod. 2014, 52, 611-616. [CrossRef]

159. Behera, G.C.; Parida, K.M.; Das, D.P. Facile fabrication of aluminum-promoted vanadium phosphate: A highly active heterogeneous catalyst for isopropylation of toluene to cymene. J. Catal. 2012, 289, 190-198. [CrossRef]

160. Bonjardim, L.R.; Cunha, E.S.; Guimarães, A.G.; Santana, M.F.; Oliveira, M.G.; Serafini, M.R.; Araújo, A.A.; Antoniolli, A.R.; Cavalcanti, S.C.; Santos, M.R.; et al. Evaluation of the anti-inflammatory and antinociceptive properties of p-cymene in mice. Z. Für Nat. C 2012, 67, 15-21. [CrossRef]

161. Nabavi, S.M.; Marchese, A.; Izadi, M.; Curti, V.; Daglia, M.; Nabavi, S.F. Plants belonging to the genus Thymus as antibacterial agents: From farm to pharmacy. Food Chem. 2015, 173, 339-347. [CrossRef]

162. Nickavar, B.; Adeli, A.; Nickavar, A. TLC-Bioautography and GC-MS Analyses for Detection and Identification of Antioxidant Constituents of Trachyspermum copticum Essential Oil. Iran. J. Pharm. Res. 2014, 13, 127-133.

163. Lotfi, P.; Yaghmaei, P.; Ebrahim-Habibi, A. Cymene and Metformin treatment effect on biochemical parameters of male NMRI mice fed with high fat diet. J. Diabetes Metab. Disord. 2015, 14, 52. [CrossRef] 
164. Joglekar, M.; Panaskar, S.; Arvindekar, A. Inhibition of advanced glycation end product formation by cymene-A common food constituent. J. Funct. Foods 2013, 6, 107-115. [CrossRef]

165. Oz, M.; El Nebrisi, E.G.; Yang, K.S.; Howarth, F.C.; Al Kury, L.T. Cellular and Molecular Targets of Menthol Actions. Front. Pharmacol. 2017, 8, 472. [CrossRef] [PubMed]

166. Patel, T.; Ishiuji, Y.; Yosipovitch, G. Menthol: A refreshing look at this ancient compound. J. Am. Acad. Dermatol. 2007, 57, 873-878. [CrossRef] [PubMed]

167. Muruganathan, U.; Srinivasan, S.; Vinothkumar, V. Antidiabetogenic efficiency of menthol, improves glucose homeostasis and attenuates pancreatic $\beta$-cell apoptosis in streptozotocin-nicotinamide induced experimental rats through ameliorating glucose metabolic enzymes. Biomed. Pharmacother. Biomed. Pharmacother. 2017, 92, 229-239. [CrossRef]

168. Khare, P.; Mangal, P.; Baboota, R.K.; Jagtap, S.; Kumar, V.; Singh, D.P.; Boparai, R.K.; Sharma, S.S.; Khardori, R.; Bhadada, S.K.; et al. Involvement of Glucagon in Preventive Effect of Menthol Against High Fat Diet Induced Obesity in Mice. Front. Pharmacol. 2018, 9, 1244. [CrossRef]

169. Ceylan, E.; Özbek, H.; Aðaoðlu, Z. Investigation of The Level of The Median Lethal Dose (LD 50) and The Hypoglycemic Effect of Cuminum cyminum L. Fruit Essential Oil Extract in Healthy and Diabetic Mice. Van Tip. Derg. (Van Med. J.) 2003, 10, $29-35$.

170. Peña-Montes, D.J.; Huerta-Cervantes, M.; Ríos-Silva, M.; Trujillo, X.; Huerta, M.; Noriega-Cisneros, R.; Salgado-Garciglia, R.; Saavedra-Molina, A. Protective Effect of the Hexanic Extract of Eryngium carlinae Inflorescences In Vitro, in Yeast, and in Streptozotocin-Induced Diabetic Male Rats. Antioxidants 2019, 8, 73. [CrossRef] [PubMed]

171. Noriega-Cisneros, R.; Ortiz-Ávila, O.; Esquivel-Gutiérrez, E.; Clemente-Guerrero, M.; Manzo-Avalos, S.; Salgado-Garciglia, R.; Cortés-Rojo, C.; Boldogh, I.; Saavedra-Molina, A. Hypolipidemic Activity of Eryngium carlinae on Streptozotocin-Induced Diabetic Rats. Biochem. Res. Int. 2012, 2012, 603501. [CrossRef]

172. Nuzzo, D.; Galizzi, G.; Amato, A.; Terzo, S.; Picone, P.; Cristaldi, L.; Mulè, F.; Di Carlo, M. Regular Intake of Pistachio Mitigates the Deleterious Effects of a High Fat-Diet in the Brain of Obese Mice. Antioxidants 2020, 9, 317. [CrossRef] [PubMed]

173. Bagheri, S.; Sarabi, M.M.; Khosravi, P.; Khorramabadi, R.M.; Veiskarami, S.; Ahmadvand, H.; Keshvari, M. Effects of Pistacia atlantica on Oxidative Stress Markers and Antioxidant Enzymes Expression in Diabetic Rats. J. Am. Coll. Nutr. 2019, 38, 267-274. [CrossRef] [PubMed]

174. Höld, K.M.; Sirisoma, N.S.; Ikeda, T.; Narahashi, T.; Casida, J.E. Alpha-thujone (the active component of absinthe): Gammaaminobutyric acid type A receptor modulation and metabolic detoxification. Proc. Natl. Acad. Sci. USA 2000, 97, 3826-3831. [CrossRef]

175. Baddar, N.W.; Aburjai, T.A.; Taha, M.O.; Disi, A.M. Thujone corrects cholesterol and triglyceride profiles in diabetic rat model. Nat. Prod. Res. 2011, 25, 1180-1184. [CrossRef]

176. Alkhateeb, H.; Chabowski, A.; Glatz, J.F.; Luiken, J.F.; Bonen, A. Two phases of palmitate-induced insulin resistance in skeletal muscle: Impaired GLUT4 translocation is followed by a reduced GLUT4 intrinsic activity. Am. J. Physiol. Endocrinol. Metab. 2007, 293, E783-E793. [CrossRef] [PubMed]

177. Alkhateeb, H.; Bonen, A. Thujone, a component of medicinal herbs, rescues palmitate-induced insulin resistance in skeletal muscle. Am. J. Physiol. Regul. Integr. Comp. Physiol. 2010, 299, R804-R812. [CrossRef] [PubMed]

178. Lachenmeier, D.W.; Walch, S.G. The choice of thujone as drug for diabetes. Nat. Prod. Res. 2011, 25, 1890-1892. [CrossRef]

179. Lindmark-Henriksson, M.; Isaksson, D.; Vanek, T.; Valterová, I.; Högberg, H.E.; Sjödin, K. Transformation of terpenes using a Picea abies suspension culture. J. Biotechnol. 2004, 107, 173-184. [CrossRef]

180. Vibha, J.; Choudhary, K.; Singh, M.; Rathore, M.; Shekhawat, N. A Study on Pharmacokinetics and Therapeutic Efficacy of Glycyrrhiza glabra: A Miracle Medicinal Herb. Bot. Res. Int. 2009, 2, 157-163.

181. Ayyasamy, R.; Leelavinothan, P. Myrtenal alleviates hyperglycaemia, hyperlipidaemia and improves pancreatic insulin level in STZ-induced diabetic rats. Pharm. Biol. 2016, 54, 2521-2527. [CrossRef]

182. Rathinam, A.; Pari, L.; Chandramohan, R.; Sheikh, B.A. Histopathological findings of the pancreas, liver, and carbohydrate metabolizing enzymes in STZ-induced diabetic rats improved by administration of myrtenal. J. Physiol. Biochem. 2014, 70, 935-946. [CrossRef]

183. Rathinam, A.; Pari, L. Myrtenal ameliorates hyperglycemia by enhancing GLUT2 through Akt in the skeletal muscle and liver of diabetic rats. Chem.-Biol. Interact. 2016, 256, 161-166. [CrossRef] [PubMed]

184. Rathinam, A.; Pari, L.; Venkatesan, M.; Munusamy, S. Myrtenal attenuates oxidative stress and inflammation in a rat model of streptozotocin-induced diabetes. Arch. Physiol. Biochem. 2019, 1-9. [CrossRef] [PubMed]

185. Neves, G.N.; Nogueira, G.; Vardanega, R.; Meireles, M.A. Identification and quantification of genipin and geniposide from Genipa americana L. by HPLC-DAD using a fused-core column. Food Sci. Technol. 2018, 38, 116-122. [CrossRef]

186. Wang, S.C.; Liao, H.J.; Lee, W.C.; Huang, C.M.; Tsai, T.H. Using orthogonal array to obtain gradient liquid chromatography conditions of enhanced peak intensity to determine geniposide and genipin with electrospray tandem mass spectrometry. $J$. Chromatogr. A 2008, 1212, 68-75. [CrossRef]

187. Shanmugam, M.K.; Shen, H.; Tang, F.R.; Arfuso, F.; Rajesh, M.; Wang, L.; Kumar, A.P.; Bian, J.; Goh, B.C.; Bishayee, A.; et al. Potential role of genipin in cancer therapy. Pharmacol. Res. 2018, 133, 195-200. [CrossRef] [PubMed]

188. Wang, J.; Zhang, Y.; Liu, R.; Li, X.; Cui, Y.; Qu, L. Geniposide protects against acute alcohol-induced liver injury in mice via up-regulating the expression of the main antioxidant enzymes. Can. J. Physiol. Pharmacol. 2015, 93, 261-267. [CrossRef] 
189. Koo, H.J.; Lim, K.H.; Jung, H.J.; Park, E.H. Anti-inflammatory evaluation of gardenia extract, geniposide and genipin. J. Ethnopharmacol. 2006, 103, 496-500. [CrossRef]

190. Jiang, Y.Q.; Chang, G.L.; Wang, Y.; Zhang, D.Y.; Cao, L.; Liu, J. Geniposide Prevents Hypoxia/Reoxygenation-Induced Apoptosis in H9c2 Cells: Improvement of Mitochondrial Dysfunction and Activation of GLP-1R and the PI3K/AKT Signaling Pathway. Cell Physiol. Biochem. 2016, 39, 407-421. [CrossRef]

191. Ma, C.J.; Nie, A.F.; Zhang, Z.J.; Zhang, Z.G.; Du, L.; Li, X.Y.; Ning, G. Genipin stimulates glucose transport in C2C12 myotubes via an IRS-1 and calcium-dependent mechanism. J. Endocrinol. 2013, 216, 353-362. [CrossRef]

192. Guan, L.; Feng, H.; Gong, D.; Zhao, X.; Cai, L.; Wu, Q.; Yuan, B.; Yang, M.; Zhao, J.; Zou, Y. Genipin ameliorates age-related insulin resistance through inhibiting hepatic oxidative stress and mitochondrial dysfunction. Exp. Gerontol. 2013, 48, 1387-1394. [CrossRef]

193. Guan, L.; Gong, D.; Yang, S.; Shen, N.; Zhang, S.; Li, Y.; Wu, Q.; Yuan, B.; Sun, Y.; Dai, N.; et al. Genipin ameliorates diet-induced obesity via promoting lipid mobilization and browning of white adipose tissue in rats. Phytother. Res. PTR 2018, 32, 723-732. [CrossRef] [PubMed]

194. Zhong, H.; Chen, K.; Feng, M.; Shao, W.; Wu, J.; Liang, T.; Liu, C. Genipin alleviates high-fat diet-induced hyperlipidemia and hepatic lipid accumulation in mice via miR-142a-5p/SREBP-1c axis. Febs J. 2018, 285, 501-517. [CrossRef] [PubMed]

195. Kojima, K.; Shimada, T.; Nagareda, Y.; Watanabe, M.; Ishizaki, J.; Sai, Y.; Miyamoto, K.; Aburada, M. Preventive effect of geniposide on metabolic disease status in spontaneously obese type 2 diabetic mice and free fatty acid-treated HepG2 cells. Biol. Pharm. Bull. 2011, 34, 1613-1618. [CrossRef]

196. Liu, J.; Yin, F.; Xiao, H.; Guo, L.; Gao, X. Glucagon-like peptide 1 receptor plays an essential role in geniposide attenuating lipotoxicity-induced $\beta$-cell apoptosis. Toxicol Vitr. 2012, 26, 1093-1097. [CrossRef] [PubMed]

197. Guo, L.X.; Liu, J.H.; Zheng, X.X.; Yin, Z.Y.; Kosaraju, J.; Tam, K.Y. Geniposide improves insulin production and reduces apoptosis in high glucose-induced glucotoxic insulinoma cells. Eur. J. Pharm. Sci. 2017, 110, 70-76. [CrossRef]

198. Liu, J.; Guo, L.; Yin, F.; Zhang, Y.; Liu, Z.; Wang, Y. Geniposide regulates glucose-stimulated insulin secretion possibly through controlling glucose metabolism in INS-1 cells. PLoS ONE 2013, 8, e78315. [CrossRef] [PubMed]

199. Zhang, Y.; Ding, Y.; Zhong, X.; Guo, Q.; Wang, H.; Gao, J.; Bai, T.; Ren, L.; Guo, Y.; Jiao, X.; et al. Geniposide acutely stimulates insulin secretion in pancreatic $\beta$-cells by regulating GLP-1 receptor/cAMP signaling and ion channels. Mol. Cell Endocrinol. 2016, 430, 89-96. [CrossRef]

200. Hodson, D.J.; Tarasov, A.I.; Gimeno Brias, S.; Mitchell, R.K.; Johnston, N.R.; Haghollahi, S.; Cane, M.C.; Bugliani, M.; Marchetti, P.; Bosco, D.; et al. Incretin-modulated beta cell energetics in intact islets of Langerhans. Mol. Endocrinol. 2014, $28,860-871$. [CrossRef] [PubMed]

201. Jacobson, D.A.; Kuznetsov, A.; Lopez, J.P.; Kash, S.; Ammälä, C.E.; Philipson, L.H. Kv2.1 ablation alters glucose-induced islet electrical activity, enhancing insulin secretion. Cell Metab. 2007, 6, 229-235. [CrossRef]

202. Bai, Y.; Zhu, R.; Tian, Y.; Li, R.; Chen, B.; Zhang, H.; Xia, B.; Zhao, D.; Mo, F.; Zhang, D.; et al. Catalpol in Diabetes and its Complications: A Review of Pharmacology, Pharmacokinetics, and Safety. Molecules 2019, 24, 3302. [CrossRef] [PubMed]

203. Yan, J.; Wang, C.; Jin, Y.; Meng, Q.; Liu, Q.; Liu, Z.; Liu, K.; Sun, H. Catalpol ameliorates hepatic insulin resistance in type 2 diabetes through acting on AMPK/NOX4/PI3K/AKT pathway. Pharmacol. Res. 2018, 130, 466-480. [CrossRef] [PubMed]

204. Bao, Q.; Shen, X.; Qian, L.; Gong, C.; Nie, M.; Dong, Y. Anti-diabetic activities of catalpol in db/db mice. Korean J. Physiol. Pharmacol. 2016, 20, 153-160. [CrossRef] [PubMed]

205. Liu, J.; Zhang, H.R.; Hou, Y.B.; Jing, X.L.; Song, X.Y.; Shen, X.P. Global gene expression analysis in liver of db/db mice treated with catalpol. Chin. J. Nat. Med. 2018, 16, 590-598. [CrossRef]

206. Trembath, D.G. Chapter 26-Molecular Testing for Glioblastoma. In Diagnostic Molecular Pathology; Coleman, W.B., Tsongalis, G.J., Eds.; Academic Press: Cambridge, MA, USA, 2017; pp. 339-347.

207. Kim, Y.; Kim, E.Y.; Seo, Y.M.; Yoon, T.K.; Lee, W.S.; Lee, K.A. Function of the pentose phosphate pathway and its key enzyme, transketolase, in the regulation of the meiotic cell cycle in oocytes. Clin. Exp. Reprod. Med. 2012, 39, 58-67. [CrossRef]

208. Wang, Y.; Jiang, Z.-T.; Li, R. Antioxidant Activity, Free Radical Scavenging Potential and Chemical Composition of Litsea cubeba Essential Oil. J. Essent. Oil-Bear. Plants JEOP 2012, 15, 134-143. [CrossRef]

209. Sousa, C.; Leitão, A.J.; Neves, B.M.; Judas, F.; Cavaleiro, C.; Mendes, A.F. Standardised comparison of limonene-derived monoterpenes identifies structural determinants of anti-inflammatory activity. Sci. Rep. 2020, 10, 7199. [CrossRef]

210. Nazzaro, F.; Fratianni, F.; De Martino, L.; Coppola, R.; De Feo, V. Effect of essential oils on pathogenic bacteria. Pharmaceuticals 2013, 6, 1451-1474. [CrossRef]

211. Boskabady, M.H.; Jandaghi, P. Relaxant effects of carvacrol on guinea pig tracheal chains and its possible mechanisms. Pharmazie 2003, 58, 661-663.

212. Brum, L.F.; Elisabetsky, E.; Souza, D. Effects of linalool on [(3)H]MK801 and [(3)H] muscimol binding in mouse cortical membranes. Phytother. Res. 2001, 15, 422-425. [CrossRef]

213. Koroch, A.R.; Rodolfo Juliani, H.; Zygadlo, J.A. Bioactivity of Essential Oils and Their Components. In Flavours and Fragrances: Chemistry, Bioprocessing and Sustainability; Berger, R.G., Ed.; Springer: Berlin/Heidelberg, Germany, 2007; pp. 87-115.

214. Wojdyło, A.; Oszmiański, J.; Czemerys, R. Antioxidant activity and phenolic compounds in 32 selected herbs. Food Chem. 2007, 105, 940-949. [CrossRef]

215. Zunino, M.P.; Zygadlo, J.A. Effect of monoterpenes on lipid oxidation in maize. Planta 2004, 219, 303-309. 
216. Javan, A.J.; Javan, M.J. Electronic structure of some thymol derivatives correlated with the radical scavenging activity: Theoretical study. Food Chem. 2014, 165, 451-459. [CrossRef] [PubMed]

217. Malmir, M.; Gohari, A.R.; Saeidnia, S.; Silva, O. A new bioactive monoterpene-flavonoid from Satureja khuzistanica. Fitoterapia 2015, 105, 107-112. [CrossRef]

218. Forbes, J.M.; Cooper, M.E. Mechanisms of diabetic complications. Physiol. Rev. 2013, 93, 137-188. [CrossRef] [PubMed]

219. Patel, D.K.; Kumar, R.; Laloo, D.; Hemalatha, S. Diabetes mellitus: An overview on its pharmacological aspects and reported medicinal plants having antidiabetic activity. Asian Pac. J. Trop. Biomed. 2012, 2, 411-420. [CrossRef] 